\title{
VARIANTY METODIKY PREZENTÁCIE HODNOTNÝCH VRSTIEV A NÁLEZOV INTERIÉRU KOSTOLA SV. MARGITY ANTIOCHIJSKEJ V KOPČANOCH
}

\author{
ANDREJ BOTEK - RÓBERT ERDÉLYI - BARBORA VACHOVÁ
}

\begin{abstract}
Abstrakt: Stáročný vývoj, ktorým Kostol sv. Margity Antiochijskej v Kopčanoch prešiel, sa zapisal do jeho podoby skladbou interiérových omietkových úprav, výmalieb, výzdob, architektonických článkov a pod., tvoriacich jeho neodmyslitel’nú hodnotovú bázu, ktorá vypovedá o jednotlivých koncepciách zásahov. Ich nositel'om je predovšetkým interiér, ked’že exteriér je výrazne poznačený úbytkom povrchových vrstiev, $z$ ktorých ostali v podstate len minimálne fragmenty. Naproti tomu interiér obsahuje stále vrstvy a situácie, ktoré predstavujú dôležitý súbor, vypovedajúci o kvalitách týchto úprav. Práve táto skutočnost' umožňuje uvažovat'o spôsobe obnovy v zásade nezávisle od vol'by princípov obnovy exteriéru. Poznatky o hodnotových vrstvách a význame objektu sa samozrejme premietajú do zložitosti metodických otázok jeho obnovy a prezentácie. Navyše objekt už poznačili rôzne čiastkové úkony, ktoré treba rešpektovat'. Autori v rámci architektonicko-historického výskumu štítov spracovali aj tri varianty metodiky obnovy a prezentácie celého interiéru, ktoré v nasledovnom príspevku približujú k odbornej diskusii.
\end{abstract}

Kl'účové slová: Kostol sv. Margity Antiochijskej-omietkové vrstvy - výzdoby - výmal'by - metodika - obnovy a prezentácie - interiér.

Methodology Versions of the Presentation of Value Layers and Finds from the Interior of the Church of St. Margaret of Antioch in Kopčany

Abstract: The history of the Church of St. Margaret of Antioch in Kopčany spanning a hundred years is reflected in the interior plastering, painting, decorations, architectural elements and others. These components make up an inimitable major value base of the building, bearing witness of its individual modification concepts. These were chiefly applied in the interior, as the exterior shows sparse surface layers of which only fragments have survived. In contrast, the interior contains permanent layers that constitute an important series illustrating the qualities of these modifications. This enables the researchers to consider the manner of the restoration of the interior independently of the restoration of the exterior. Information about value layers and the importance of the building is naturally projected into the complex issues of the methodology of its restoration and presentation. In addition, the building has been the subject of some partial modifications that need to be respected. Within architectural and historical research into gables, the authors produced three versions of the methodology of the restoration and presentation of the interior which they submit to a specialist discussion by way of this contribution.

Key words: Church of St. Margaret of Antioch - plaster layers - decorations - interior decoration - methodology - restorations and presentations - interior.

Kostol sv. Margity Antiochijskej v chotárnom území obce Kopčany je verejnosti známy už desat' rokov najmä vd’aka svojej medializácii ako jedinej stojacej vel'komoravskej architektúry na území bývalého Československa (Baxa a kol. 2004, 65), čo pritiahlo pozornost' a širokú publicitu, ale prekrylo d’alší bohatý stáročný vývoj, ktorým tento objekt prešiel a ktorý sa prejavuje v rôznorodých zachovaných úpravách, detailoch i vrstvách.

Objekt dlhé roky unikal záujmu odborníkov a bol považovaný za barokovú kaplnku. Výskum zo 60. rokov 20. storočia (L’udmila Kraskovská) posunul toto datovanie do obdobia gotiky (Baxa a kol. 2005, 48). Archaická hmotová skladba, vel'komoravské sídliskové nálezy v okolí i blízkost' mikulčického hradiska Valy vyvolávali úvahy o vel'komoravskej tradícii. Prispeli k tomu aj postrehy prof. Antona Bagina o miestnom slávení patrocínia, ktoré sa udržalo v dátume platnom do 12. storočia $(1992,13)$. Patrocínium, ako dôležitý atribút sakrálneho objektu, má vypovedaciu schopnost' aj pre usudzovanie o dobe jeho vzniku, ale nemusí íst' vždy o priame, ale aj o následne sprostredkované vplyvy (Kvasnicová 2007, 60-61). Oživenie záujmu vyvolala aktivita miestneho kronikára (Vladimír Grigar) začiatkom 90. rokov, ktorý oslovil pedagógov Filozofickej fakulty Univerzity Komenského a na jeho podnet tu študenti v roku 1994 realizovali niekol'ko 


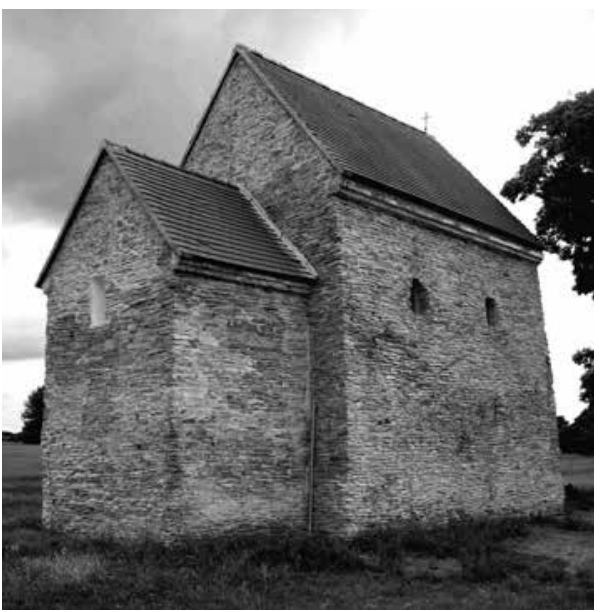

Obr. 1. Kopčany, okr. Senica, Kostol sv. Margity Antiochijskej. Pohl'ad zo severovýchodu.

Abb. 1. Kopčany, Bezirk Senica, Kirche St. Margaretha von Antiochien. Blick von Nordosten. sond. Následne bol spracovaný návrh na zápis do ÚZ NKP a začali systematické výskumy. Architektonicko-historický výskum realizoval od roku 1994 vtedajší Slovenský pamiatkový ústav - Regionálne stredisko Bratislava (Elena Sabadošová, Marián Havlík) paralelne $\mathrm{s}$ archeologickým výskumom Záhorského múzea v Skalici (Viera Drahošová). Reštaurátorský výskum objektu vykonávala od roku 1996 Katedra reštaurovania Vysokej školy výtvarných umení (Vladimír Úradníček, Andrej Botek) s dôrazom na jeho interiér. ${ }^{1}$

Od konca 90. rokov realizoval archeologický výskum Peter Baxa. Čiastkové výskumy prebehli na začiatku 21. storočia (štít Ján Hromada, okno svätyne - Ján Sikoriak) a neskôr kostol $\mathrm{v}$ exteriéri v niekol'kých etapách $(2001,2003,2004,2006,2009)$ - v súvislosti s lokálnou reštaurátorskou obnovou a odstraňovaním omietok - skúmali Juraj

Puškár a Vojtech Mýtnik. V roku 2008 vypracovali Elena Sabadošová a Marián Havlík výskum západnej a južnej fasády (Sabadošová-Havlík 2008). V kolektíve Andrej Botek, Róbert Erdélyi a Barbora Vachová sme v roku 2011 realizovali architektonicko-historický výskum interiérov štítov (Botek-Erdélyi-Vachová 2011). Od roku 2013 vykonáva doplnkový reštaurátorský výskum interiéru Marián Keleši, zatial' bez publikovania.

Viacero interiérových omietkových úprav, výmalieb, výzdob, architektonických prvkov a pod., ktorými sa do podoby interiéru Kostola sv. Margity Antiochijskej v Kopčanoch zapísal stáročný vývoj, vytvára hodnotovú bázu, ktorá nás núti nepostupovat' v prípade jeho obnovy šablónovito, ale dôsledne premysliet' jednotlivé možnosti tak, aby sme príslušnou vol'bou metodiky nespôsobili nenávratné škody na hodnotovom fonde. Práve spomínaný výskyt viacerých hodnotných úprav a vrstiev umožňuje uvažovat' o princípe obnovy variantným spôsobom s tým, že v konečnom dôsledku, pri dôslednej ochrane nálezov možno v celkovej prezentácii volit' medzi rôznymi výrazovými kvalitami. Zvolená metodika obnovy musí vychádzat' zo zohl'adnení všetkých súvislostí, hodnôt a nielen dôležitosti primárnej etapy, ale dokladu celého stáročného vývoja tejto najstaršej pamiatky na našom území.

Treba poukázat' aj na dôležitost' Kopčian vo vzt’ahu s areálom Valov pri Mikulčiciach na Morave. ${ }^{2}$ Tieto súvislosti predpokladajú riešenie v širokých urbanisticko-krajinných vzt’ahoch nadregionálneho významu. Základnou osou sa stáva rekonštruovaná vel'komoravská trasa, ktorá na moravskej strane viaže pamiatkové objekty obce Mikulčice a vel'komoravské sídlisko Valy, na slovenskej strane Kostol sv. Margity a potenciál kultúrnej barokovej krajiny s unikátnymi architektonickými a prírodnými prvkami (Pauliny 2007, 16). ${ }^{3}$

\section{Súhrn najdôležitejších nálezov úprav a výzdob}

Na interiérových plochách stien je zachovaný výskyt viacerých historických úprav - omietok a náterov s výzdobami, ale aj viaceré zásahy - úpravy murív a architektonických prvkov

\footnotetext{
1 Výskumu sa postupne zúčastnili aj študenti katedry Keleši, Poštek, Havasi, Holomáň a Slúka.

2 Už začiatkom tretieho tisícročia vznikla myšlienka vybudovania medzinárodného archeologického parku Mikulčice - Kopčany a tieto lokality boli i spoločne podané na návrh zápisu do svetového kultúrneho dedičstva.

3 Návrh riešil v rámci grantovej úlohy na Fakulte architektúry STU kolektív Gregor, Gregorová, Pauliny, Škrovina, Vaščák. Architektonicko-urbanistickú štúdiu riešili Gregorová, Ilkovič, Pauliny.
} 


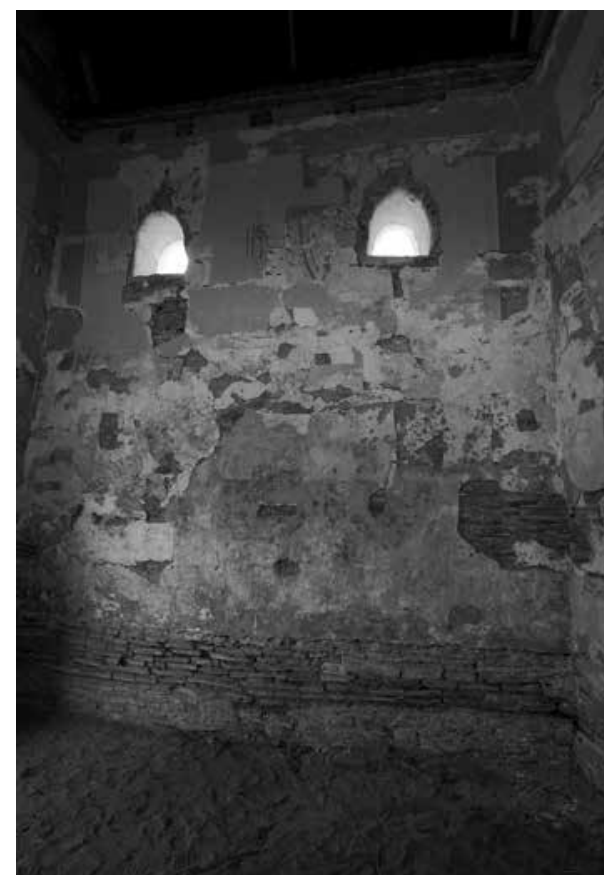

Obr. 2. Kopčany, okr. Senica, Kostol sv. Margity Antiochijskej. Severná stena po odkryvoch.

Abb. 2. Kopčany, Bezirk Senica, Kirche St. Margaretha von Antiochien. Nordwand nach den Freilegungen.

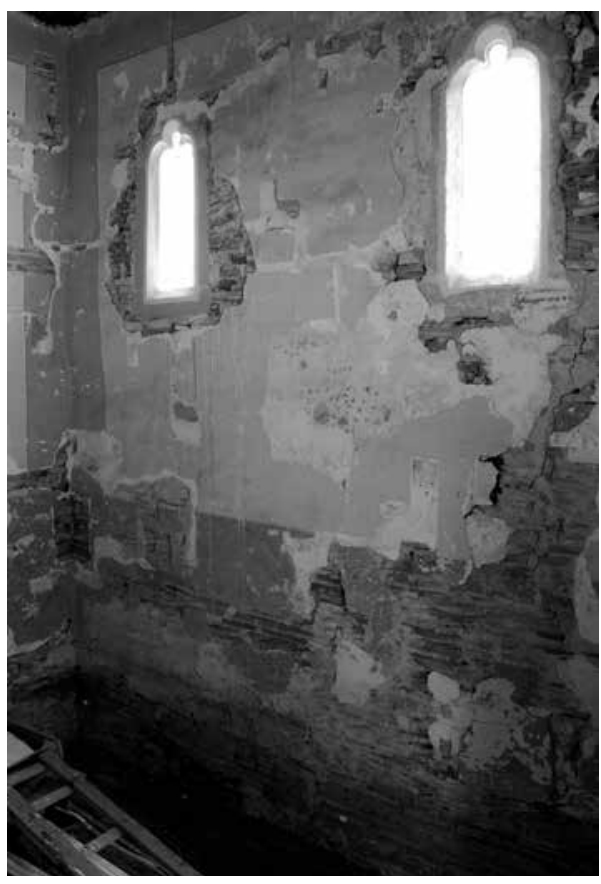

Obr. 3. Kopčany, okr. Senica, Kostol sv. Margity Antiochijskej. Južná stena po čiastkovej obnove.

Abb. 3. Kopčany, Bezirk Senica, Kirchte St. Margaretha von Antiochien. Südwand nach teilweiser Restaurierung.

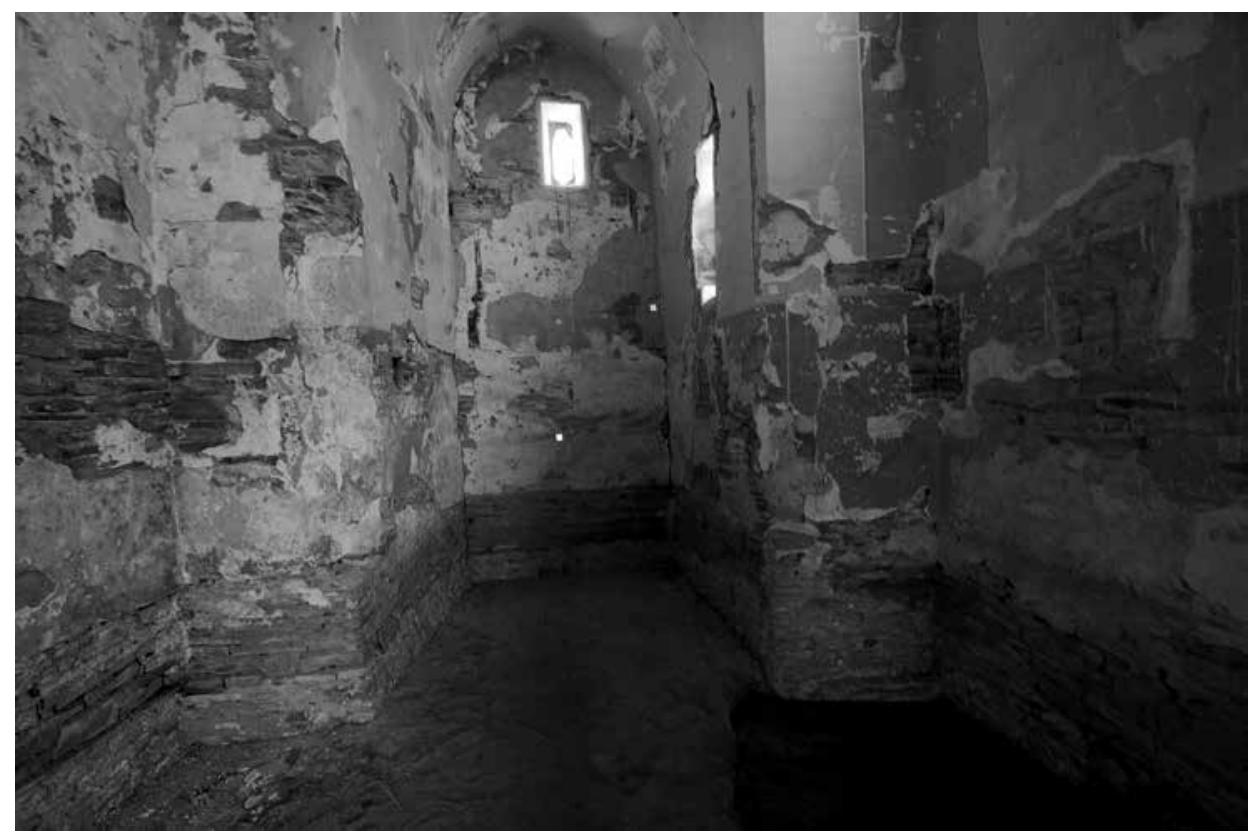

Obr. 4. Kopčany, okr. Senica, Kostol sv. Margity Antiochijskej. Východná stena po odkryvoch so zvyškami iluzívnej výzdoby. Abb. 4. Kopčany, Bezirk Senica, Kirche St. Margaretha von Antiochien. Ostwand nach den Freilegungen mit Resten der illusionistischen Verzierung. 


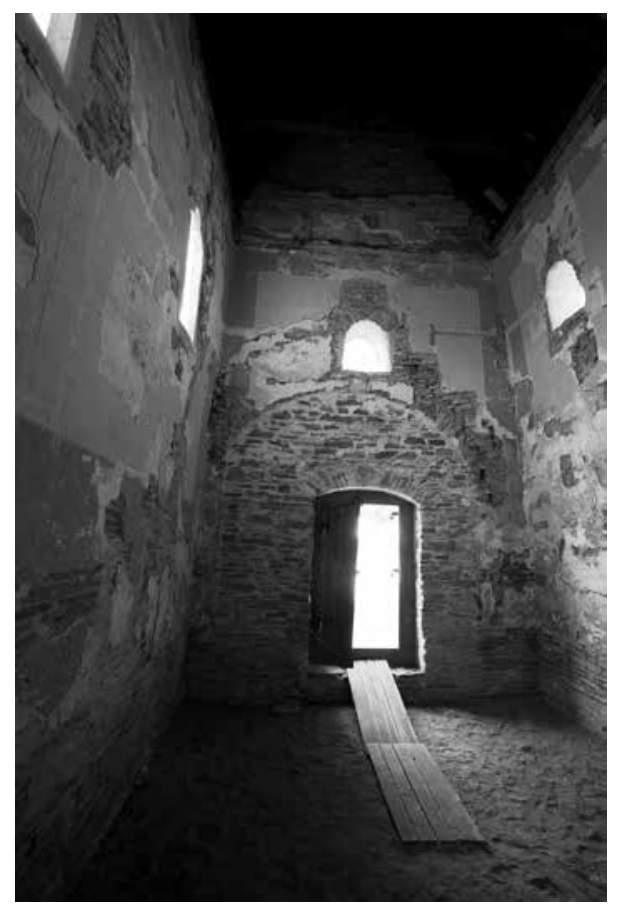

Obr. 5. Kopčany, okr. Senica, Kostol sv. Margity Antiochijskej. Západná stena po čiastkovej obnove.

Abb. 5. Kopčany, Bezirk Senica, Kirche St. Margaretha von Antiochien. Westwand nach teilweiser Restaurierung. (okná, vstup, podlahové úrovne, menza a pod.). Spomeňme najdôležitejšie výzdoby a nálezy. ${ }^{4} \mathrm{Z}$ primárnej etapy (koniec 9 . až začiatok 10. storočia) je to najmä murivo objektu, ktoré reprezentuje dodnes zachovaný hmotový rozsah lode a rovného záveru, pôvodné bočné murivá siahajú takmer ku korunnej rímse. V rozsahu štítov reprezentuje pôvodnú etapu terajší hrúbkový odskok. Zachované sú dve primárne okná na severnej stene, spodná čast' primárneho okna na západnom priečelí, východná čast' okna na južnej stene lode a čast' špalety primárneho okna na južnej stene lode $v$ mieste západného okna. Povrchové úpravy sú zistené ako fragmenty s ojedinelými zvyškami čiernej a červenej polychrómie, ${ }^{5}$ pričom ich príslušnost' $\mathrm{k}$ tejto etape zatial' nie je jednoznačne doložená. Fragmenty druhej úpravy, ktorá bola len celkovým preomietnutím bez stavebných zmien (ca 11.-12. storočie), nesú na západnom štíte zvyšky sivohnedého členenia. Nový výskum (Marián Keleši) odkryl v hornej časti steny aj čast' mal'ovanej dvojice oblúkov (arkády?, svätožiary?). Výskum interiérov štítov nám umožňuje s najväčšou pravdepodobnost'ou usudzovat', že v primárnej fáze bola zaklenutá aj lod' (Botek-Erdélyi-Vachová 2013, 39). ${ }^{6}$

Svedčí o tom aj vysoko položený fragment v poradí druhej omietky s výzdobou, ktorý sa neskôr dostal nad úroveň mladšieho stropu, ako aj fragment omietky v kúte so šikmým nábehom.

Z obdobia ca prelomu 13.-14. storočia na juhu svätyne na mieste pôvodného okna vytvorili nové hrotité okno s kamenným mníškovým rámom, s kruhovou perforáciou vo vrchole. Následne celoplošne preomietli interiér. Severnú stenu lode pokrýva sivohnedá omietka s pieskovou štruktúrou povrchu a s hladším povrchom na južnej stene. Na severnej stene lode sú na omietke v mieste zámurovky primárneho okna zvyšky vel'korozmernej mandorly s dúhovou lavičkou (pokračovala nad úroveň novodobého stropu), fragmentmi svätožiary a vlasov postavy. Má široký lem z červených, ružových, tyrkysových a sivookrových pruhov. Ústredný motív (tróniaci Kristus?) v mieste zámurovky staršieho okna sa nezachoval. ${ }^{7}$

Okolo polovice 14. storočia osadili na južnú stenu lode do miesta primárnych otvorov okná s mníškovým ukončením. Západné okno bolo zachované celé s tým, že ho neskôr zmenšili a následne úplne zamurovali. $Z$ východného okna sa zachovalo len horné ukončenie. Kamenné články majú vápenné nátery, ojedinele so zružoveným tónom. $Z$ tohto obdobia pochádza aj pravouhlé (zrejme premurované) okno v závere svätyne s doskovou výplňou s výrezom. V 15. storočí dochádza k zániku predsiene a k osadeniu širokého portálu do západnej steny, čo si vyžiadalo i premurovanie nároží a zásahy eliminujúce zaklonenie západného múra. Omietka na západnej stene má asi pät' náterov. Oltár vtedy premiestnili pred svätyňu do lode (nález základov - Viera

\footnotetext{
4 V nasledovnom vychádzame zo spomenutých už výskumných materiálov, z publikovaného vývoja objektu (Botek 2010), z doplnkového výskumu štítov (Botek-Erdélyi-Vachová 2011), ako aj z posledných nálezov počas doplnkového reštaurátorského výskumu M. Kelešiho.

5 Zatial' ale nie je jednoznačné, či polychrómia nesúvisí až s d'alšou úpravou.

$6 \mathrm{Na}$ oboch štítoch sa v ich bočných ukončeniach našla šikmo stúpajúca skladba muriva a fragment omietky so šikmým nábehom. Z dôvodu odstránenia primárneho muriva štítov sa tieto situácie zachovali len v malom rozsahu.

7 Po odstránení novodobého stropu terajší doplnkový reštaurátorský výskum (Marián Keleši) odkryl aj horné ukončenie mandorly a niekol’ko d'alších detailov.
} 


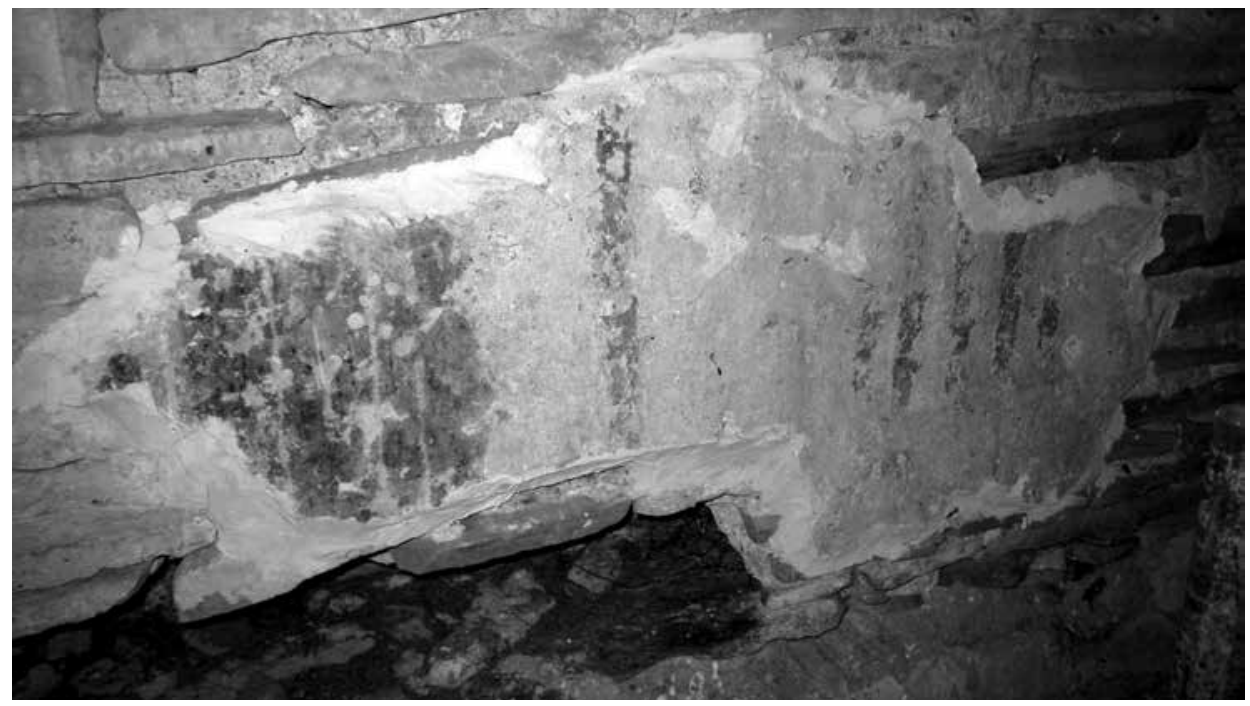

Obr. 6. Kopčany, okr. Senica, Kostol sv. Margity Antiochijskej. Omietka 2. úpravy s výzdobou na západnom štíte.

Abb. 6. Kopčany, Bezirk Senica, Kirche St. Margaretha von Antiochien. Putz der zweiten Umgestaltung mit Verzierung am Westgiebel.

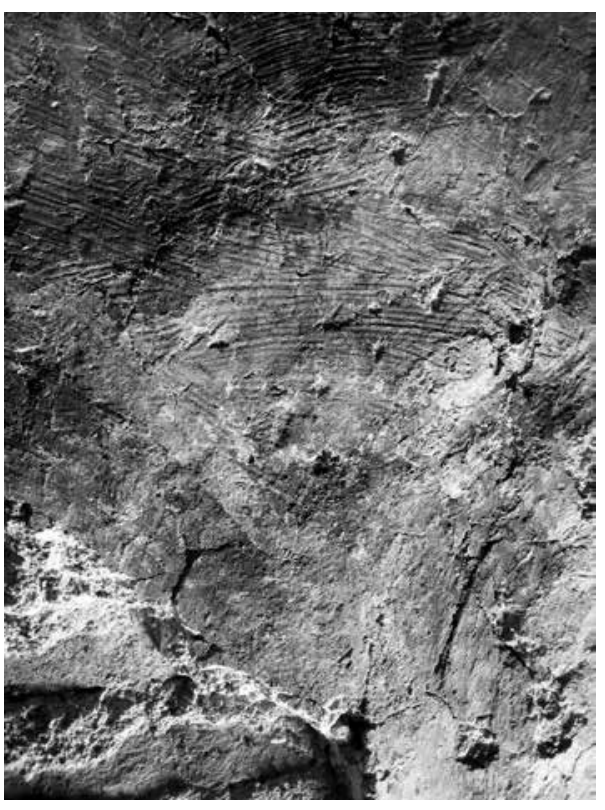

Obr. 7. Kopčany, okr. Senica, Kostol sv. Margity Antiochijskej. Omietka 2. úpravy so zvyškami výzdoby na západnej stene. Abb. 7. Kopčany, Bezirk Senica, Kirche St. Margaretha von Antiochien. Putz der zweiten Umgestaltung mit Resten der Verzierungen an der Westwand.
Drahošová), takže museli zosekat' hrany stien kvôli prechodu do záveru. Na ich omietke sú zvyšky čiernej polychrómie v soklovej časti a čierna polychrómia je ojedinele vo fragmentoch na príslušnej omietkovej vrstve aj vo svätyni.

K úpravám zo 16. storočia patria fragmenty dvoch výmalieb na východnej stene, z ktorých horná vrstva zobrazuje čast' ženskej tváre (sv. Margita?), spodná pravdepodobne rastlinný výjav. Mal'ba plnila funkciu oltárneho obrazu s motívom patrocínia. Mimoriadne bohatá je výmal'ba z polovice 17. storočia na celoplošnej omietkovej vrstve v lodi i svätyni - mal'ovaný drapériový lambrekýn, ukončený strapcovým pásom (čierne, zelenomodré a okrovočervené úseky), na bočných stenách zvyšky iluzívnych pilastrov, ktoré zvýrazňovali tektoniku nezachovanej empory, na východnej stene malovaná iluzívna oltárna architektúra (oltár vtedy premiestnili na zadnú stenu a opät' zdvihli podlahu), na klenbe figurálne výjavy v oblakoch. Súčasný výskum (Marián Keleši) odokryl orámovaný figurálny výjav na južnej stene lode (na perspektívne ubiehajúcej dlažbe kl'ačia dvaja rehol'níci? pred Madonou?). Na severnej stene ostal z pendantného výjavu len vták. Klenba bola pokrytá figurálnou výmal'bou vo vrchole s motívom koruny. $\mathrm{K}$ etape patria viaceré ryté nápisy, značky a letopočty 1647, ako aj úprava južného okna svätyne na výklenok. Systém výzdoby sa vo svätyni i na klenbe zopakoval v istom časovom odstupe. Zrejme k týmto dvom úpravám patria 


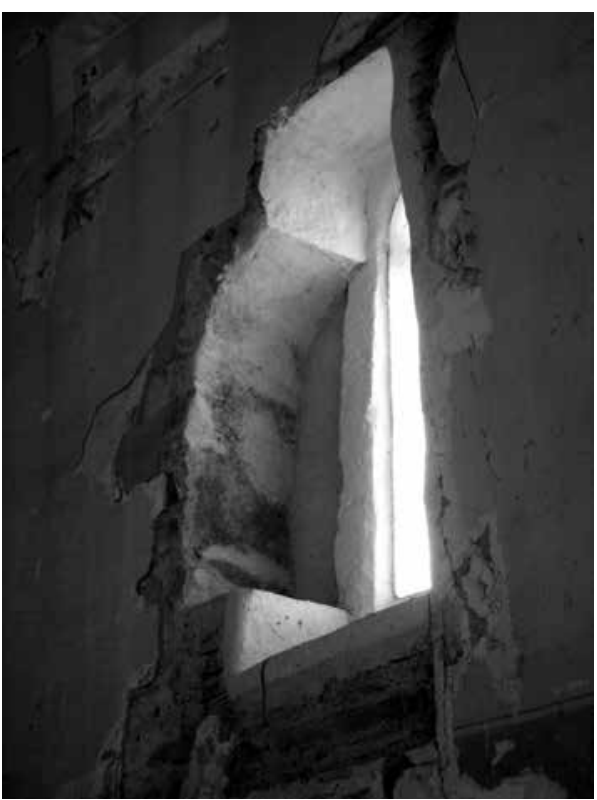

Obr. 8. Kopčany, okr. Senica, Kostol sv. Margity Antiochijskej. Súčasná prezentácia nálezov južnej steny svätyne.

Abb. 8. Kopčany, Bezirk Senica, Kirche St. Margaretha von Antiochien. Aktuelle Präsentation der an der Südwand des Chors gemachten Funde.

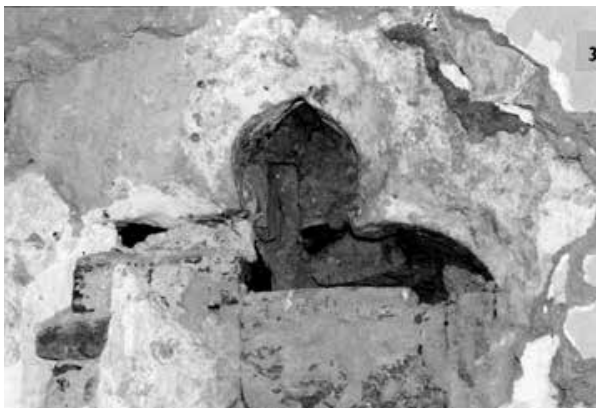

Obr. 10. Kopčany, okr. Senica, Kostol sv. Margity Antiochijskej Vrchol mníškového okna lode počas výskumu.

Abb. 10. Kopčany, Bezirk Senica, Kirche St. Margaretha von Antiochien. Scheitel des Kleeblattfensters des Schiffes während der Untersuchung.

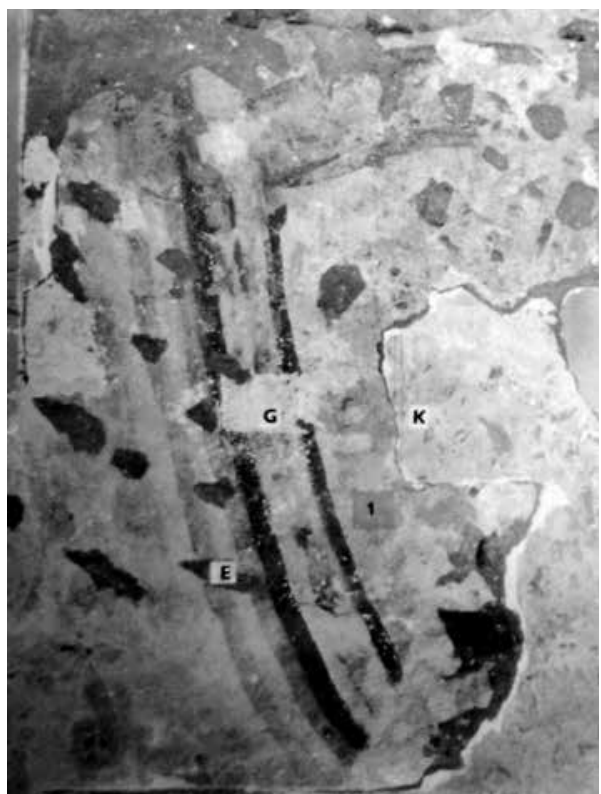

Obr. 9. Kopčany, okr. Senica, Kostol sv. Margity Antiochijskej. Detail mandorly na severnej stene počas výskumu.

Abb. 9. Kopčany, Bezirk Senica, Kirche St. Margaretha von Antiochien. Detail einer Mandorla an der Nordwand während der Untersuchung.

dva horizontálne červené pásy - jeden v úrovni niekdajšej podlahy empory, druhý pod stropom, ktoré sú tiež zopakované v dvoch vrstvách. V 18. storočí osadili na južnú stenu lode v mieste východného okna termálne okno a okolo realizovali štylizovanú florálnu výzdobu - rastlinné ornamenty a úponky. Segmentovo ukončené okienko prebúrali nad portálom. Obe okná zanikli pri nedávnych rekonštrukčných zásahoch. Z neskorších úprav (19. storočie) je to pravdepodobne imitácia dreveného retábula na bordovom pozadí na východnej stene a geometricky členený medailón vrcholu klenby, ktorý odhalil súčasný výskum (Marián Keleši).

\section{Úpravy interiéru od roku 2000}

Oproti stavu po ukončení základného reštaurátorského a architektonicko-historického výskumu (1998 a 1999) sa v interiéri uskutočnili rôzne čiastkové zásahy, ktoré dnes výrazne limitujú metodické rozhodovanie o forme prezentácie interiéru. Po roku 2000 sa odstránil strop, vymenila sa celá krovná konštrukcia a strešná krytina, pričom ostal otvorený priehl'ad do krovu. V tejto súvislosti upravili tehlovými zásahmi odvesny i korunu bočných stien, kde zamurovali aj staršie kapsy trámov. V zmysle preferencie primárnej fázy objektu (po r. 2004) došlo k celkovému zníženiu podlahovej úrovne na pôvodnú niveletu ca o $55-60 \mathrm{~cm}$, čím sa po celom obvode opticky prezentuje súvislý pás neomietaného muriva, doteraz prekrytého podlahou. Tým sa zrušilo 


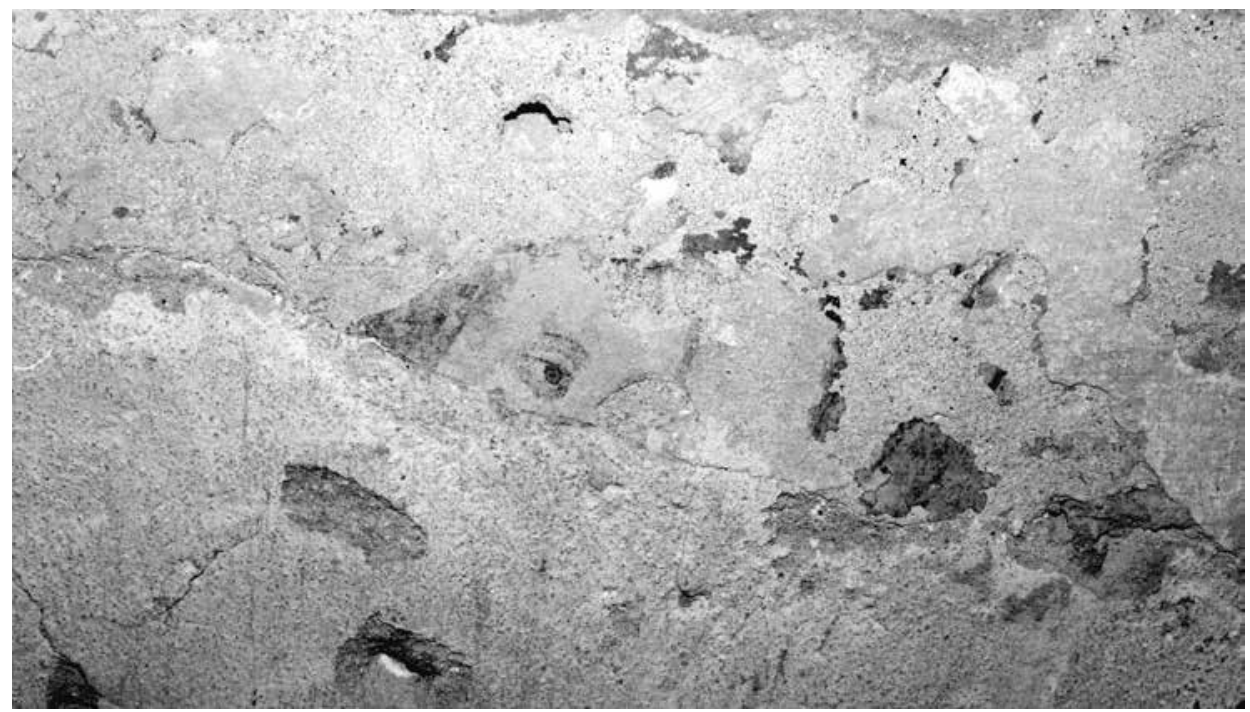

Obr. 11. Kopčany, okr. Senica, Kostol sv. Margity Antiochijskej. Fragment ženského portrétu na východnej stene (sv. Margita?). Abb. 11. Kopčany, Bezirk Senica, Kirche St. Margaretha von Antiochien. Fragment eines Frauenporträts an der Ostwand (HI. Margaretha?).

i vyvýšené oltárne plató, menzu i murovaný stipes rozobrali. Vel'ký vstupný portál zamurovali kamenným murivom a náznakovo zrekonštruovali pôvodný vstup, ${ }^{8}$ najprv so segmentovým záklenkom, neskôr bol korigovaný na drevený fošňový preklad. Mladšie okienko nad ním zrušili a v tomto mieste obnovili primárny okenný otvor. Obnovili sa aj obe primárne okná severnej steny a okno vo východnej stene záveru. Na južnej stene lode obnovili obe mníškové stredoveké okná - prvé odstránením dvoch zámuroviek, druhé sa doplnilo, čím ale zaniklo mladšie termálne okno v jeho mieste aj s rozvilinkovou výzdobou. Na južnej stene svätyne došlo k pohl'adovo najvýznamnejšiemu zásahu - odstránením zámurovky sa obnovilo ranogotické okno a východná čast' ostenia primárneho okna je prezentovaná formou analytickej sondy. Nakol'ko sme pri prvom reštaurátorskom prieskume (Botek-Úradníček 1998) chceli dostat' základný prehlad o vrstvách a ich úpravách, nerobili sme celoplošné odkryvy a rešpektovali sme miesta s mladšími výmal'bami. V súčasnosti (od 2013) v interiéri prebieha doplňujúci reštaurátorský prieskum (Marián Keleši), ktorý spresnil viaceré poznatky o úpravách a postupne realizuje d’alšie odkryvy. Jeho výsledky ešte neboli publikované.

\section{Doterajšie metodické návrhy}

Metodika obnovy interiéru bola spracovaná už niekol'kokrát, na rôznej úrovni poznania. Súčastou reštaurátorského výskumu (Botek-Úradníček 1998) bol aj Návrh obnovy a prezentácie, spracovaný v dvoch variantoch. ${ }^{9}$ Variant I. stanovil ako nosný princíp rešpektovanie všetkých hodnotových vrstiev s možnostou prezentácie dôležitých starších artefaktov formou ník a analytických prezentácií. V zásade stanovil ako nosnú úpravu zo 17. storočia s tým, že navrhol konkrétne riešenia dôležitých starších prvkov (mandorla, mníškové okná atd’.). Nerátal s otvorením primárnych okien na severnej stene, ani s odstránením zámurovky prvého mníškového okna na južnej stene lode, ale predpokladal prezentáciu výrezmi. Ponechával termálne okno na juhu s analytikou vrcholu mníškového okna nad ním. V tomto duchu riešil i ostatné situácie.

8 Malo to za následok prerazenie kamenného prahu neskorostredovekého portálu.

9 Materiál návrhu obnovy a prezentácie má v rámci uvedeného elaborátu samostatné postavenie a vlastnú pagináciu 1-14. Vid’ Botek-Úradníček 1998. 


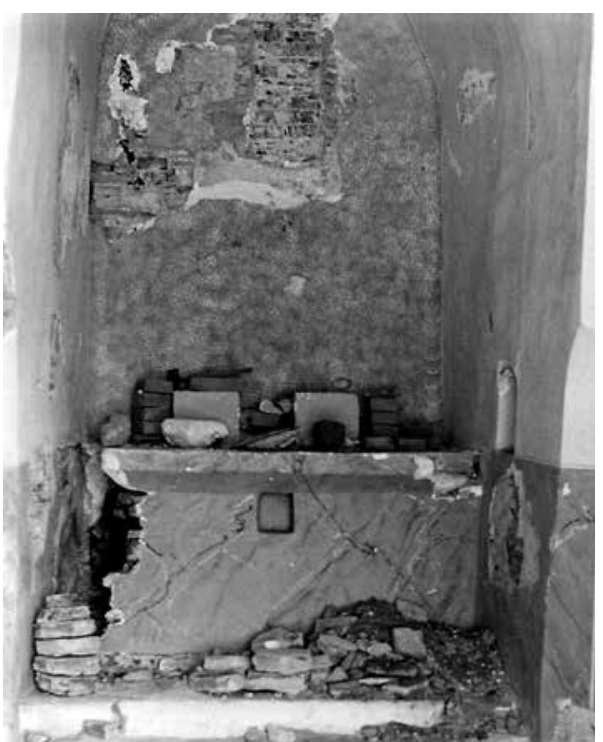

Obr. 12. Kopčany, okr. Senica, Kostol sv. Margity Antiochijskej. Východná stena s t. č. odstránenou menzou.

Abb. 12. Kopčany, Bezirk Senica, Kirche St. Margaretha von Antiochien. Ostwand mit seinerzeit entfernter Altarmensa.

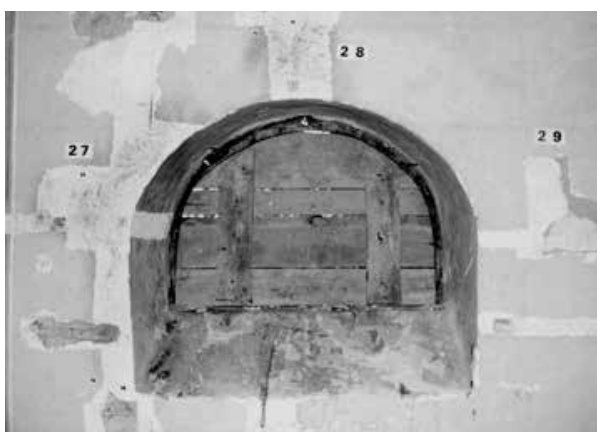

Obr. 13. Kopčany, okr. Senica, Kostol sv. Margity Antiochijskej. Zaniknuté termálne okno s výzdobou.

Abb. 13. Kopčany, Bezirk Senica, Kirche St. Margaretha von Antiochien. Entferntes Thermalfenster mit Verzierung.
Variant II. prezentoval ako nosný stredoveký výraz objektu. Neodstraňoval mladšie vrstvy, ale po ich zakonzervovaní rátal s preomietnutím imitujúcim zvolenú staršiu omietku. Pôvodné okná na severe ponechával ako niky, rátal s obnovením mníškových okien, zrušením novšieho poloblúkového okna i okna na západe a pod.

PÚ SR Bratislava vypracoval $\mathrm{v}$ roku 1999 Ideový návrh obnovy a prezentácie, ktorý bol oficiálne schválenou metodikou obnovy (Sabadošová-Havlík 1999). Vychádzal z dominantného vyznenia prvej vývojovej fázy s priznaním dôležitých nálezov neskorších etáp formou analytických prezentácií, podrobne opísaných pre konkrétne vybraté časti. V zásade šlo o konzervačnú metódu spojenú s reštitučnými, rekonštrukčnými a náznakovými princípmi. Rátal s ponechaním hodnotných omietkových vrstiev a ich preomietnutím omietkou imitujúcou pôvodný charakter. Počítal so znížením nivelety, obnovou primárneho vstupu domurovaním v náznaku, otvorením pôvodných okien na severnej i západnej stene, obnovou mníškových okien a pod.

Ďalší materiál, ktorý komplexne riešil metodiku obnovy - reštaurovania interiéru, spracovali Miroslav Šurin a Andrej Botek v roku 2008 (Šurin-Botek 2008). ${ }^{10}$ Obsahoval tri varianty riešenia, pričom stanovil vždy dôsledné fixovanie a prekrytie jestvujúcich vrstiev. Do návrhu aktualizoval aj nové poznatky. Prvý variant v zásade navrhoval dominanciu primárnej etapy a následných stredovekých úprav. V interiéri vytvorit' novú celoplošnú omietkovú vrstvu, imitujúcu charakter primárnej omietky. Analytickými sondami prezentovat' vybrané prvky. Druhý variant navrhol reštaurovanie vrstvy zo 17. storočia

a staršie vrstvy prezentovat' v závislosti od konkrétnej situácie (podrobne popisoval jednotlivé možnosti prezentácie a analytické prezentácie otvorov, zámuroviek i rôznych omietok s výzdobami, pričom zvažoval už zrealizované úpravy). Tretí variant vychádzal z princípu prezentovania interiéru ako súboru fragmentov omietkových a výzdobných vrstiev v ich kontinuálnom vývoji podl'a rozsahu zachovania, bez odkryvov (publikované podrobnejšie v Botek 2010, 47-49).

\section{Varianty obnovy a prezentácie}

Predložený návrh obnovy interiéru vznikol ako súčast' elaborátu Architektonicko-historického výskumu interiéru štítov a návrhu obnovy interiéru (Botek-Erdélyi-Vachová 2011, 53-56, 61-75 - grafické znázornenie). Preto nemohol zahrnút' skutočnosti, ktoré popisujeme vyššie 


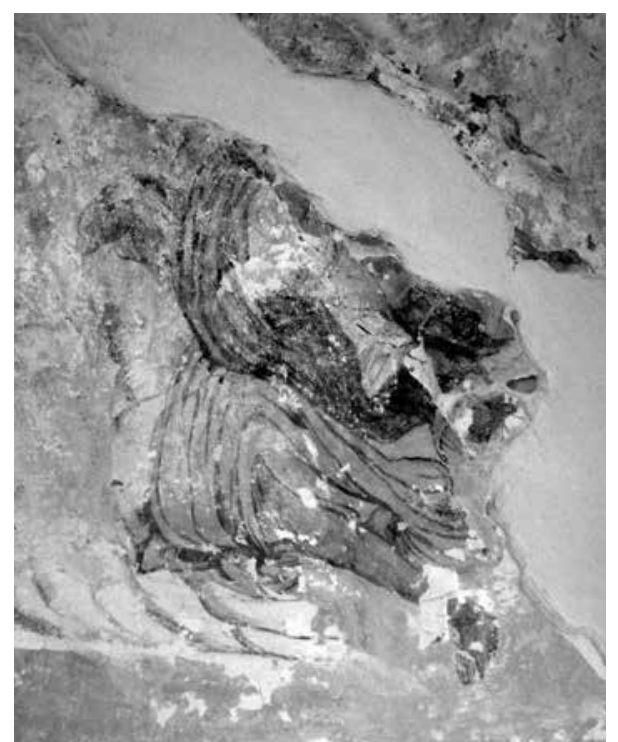

Obr. 14. Kopčany, okr. Senica, Kostol sv. Margity Antiochijskej. Figurálny fragment na klenbe.

Abb. 14. Kopčany, Bezirk Senica, Kirche St. Margaretha von Antiochien. Figuralfragment am Gewölbe. v súvislosti s doplnkovým výskumom, predpokladali sme však, že počas reštaurátorskej obnovy dôjde $\mathrm{k}$ podobným nálezom a bude nutné ich do metodiky zahrnút' (Botek-Erdélyi-Vachová 2011, 57-58).

Ak uvažujeme nad vhodnými metodickými princípmi obnovy objektu, musíme brat' do úvahy aj nové zásahy, ktoré jednak zapríčinili zánik viacerých nálezových situácií, na druhej strane zrekonštruovali a prezentovali viaceré staršie situácie. V zásade už nie je možný dôsledný návrat do poslednej dominantnej úpravy z roku 1647 - musela by sa znova dvíhat' podlažná úroveň, nanovo murovat' oltár, odstránit' zámurovku a rekonštrukciu vstupu, zrušit' rekonštrukciu mníškového okna a v jej mieste obnovit' termálne okno, aj znovu osadit' rovný strop a pod.

V súčasnosti sa $\mathrm{z}$ hodnotového hladiska konfrontujú dve významové polohy: výskyt viacerých omietkových a výzdobových vrstiev interiéru, ktoré poukazujú na bohatú

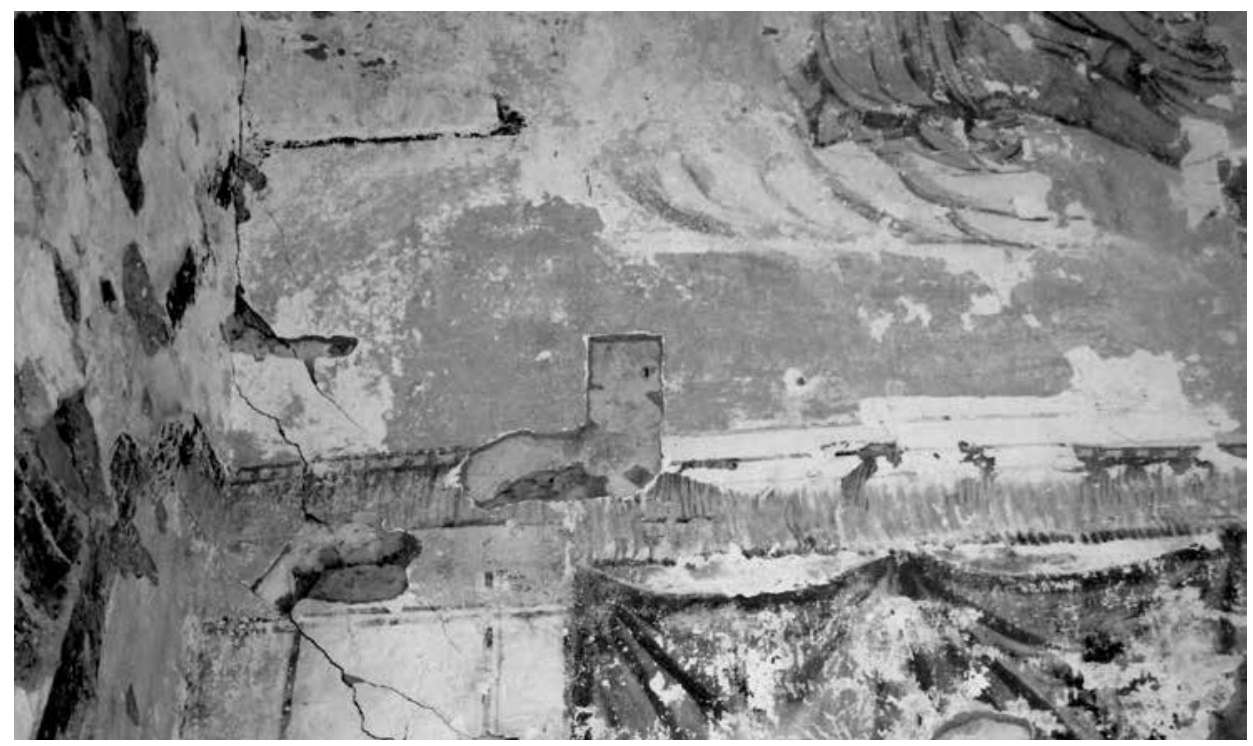

Obr. 15. Kopčany, okr. Senica, Kostol sv. Margity Antiochijskej. Dve vrstvy barokových výzdob na južnej stene svätyne.

Abb. 15. Kopčany, Bezirk Senica, Kirche St. Margaretha von Antiochien. Zwei barockzeitliche Verzierungsschichten an der Chorsüdwand.

vývojovú skladbu; a datovanie objektu do obdobia druhej polovice 9. storočia, čo stavia do popredia predovšetkým prezentáciu primárnej fázy, nadhodnocujúc tak hodnotu dobovej jedinečnosti v d’alšom vývoji (Botek 2010, 45-46). Rozhodovanie v prospech jednej (viacvrstvovost' hodnotných úprav), alebo druhej (primárna fáza) roviny hodnotenia, má t’ǎiskovú rolu v procese určenia metodiky obnovy a prezentácie. 
Základnú metodiku sme postavili na rešpektovaní všetkých hodnotových vrstiev a ich konzervovaní. Základným predpokladom kvalifikovanej obnovy je definovanie všetkých typov kultúrno-historických hodnôt tvoriacich pamiatkový obsah (Gregor 2008, 67). Nakol'ko je v interiéri zachovaná celá škála hodnotných vrstiev, maliarskych výzdob a architektonických článkov, ako aj realizovaných čiastkových rekonštrukcií, tento stav umožňuje pri dodržaní základnej metodiky uvažovat' o viacerých variantných riešeniach. Bližšie metodické usmernenia konkrétnych prezentácií, rekonštrukcií či reštitúcií sú závislé od vol'by konkrétneho variantu.

\section{Východiská}

Navrhli sme rešpektovat' súčasné pomery ako i prebehnuvšie dielčie rekonštrukcie a reštitúcie otvorov:

- Ide o prezentáciu primárnych otvorov severnej a západnej steny, otvoru východnej steny, obnovené a rekonštruované mníškové okná južnej steny lode, ako i sústavu mníškového okna svätyne s analytikou časti primárneho okna.

- V rámci úpravy zámurovky stredovekého portálu upravit' ukončenie rekonštruovaného vstupného otvoru s pravouhlým prekladom (fošňa), evokujúcim primárnu situáciu. ${ }^{11}$

- Odstránit’ najmladšie vrstvy omietok (19. a 20. storočie). Pred odstránením zdokumentovat' novšiu výzdobu východnej steny svätyne (bordová plocha, hnedé rámy s točeným vzorom), prípadne overit' jej príslušnost'. Ostatné hodnotné omietkové vrstvy s výzdobami reštaurátorsky očistit', konsolidovat', konzervovat', stabilizovat'.

- Vykonat' doplnkový reštaurátorský prieskum zameraný najmä na klenbu a na preverenie primárnych situácií.

- Predpokladáme, že aj v prípade výmeny krovnej konštrukcie nedôjde k realizácii stro$\mathrm{pu}$, ale ostane priehl'ad.

- V interiéri navrhujeme jednotnú niveletu bez výškových stupňov s liatou podlahovou úpravou (maltová, resp. hlinito-maltová), ktorej presné technologické parametre budú predmetom realizačného návrhu.

Ďalší postup je závislý od prijatia toho-ktorého konkrétneho variantu. Pre bližšie určenie omietok používame značenie podl’a Botek-Úradníček 1998. Nakol'ko predstavujeme materiál, ktorý vznikol pred najnovšími nálezmi, tieto nie sú v nasledovnom síce spomenuté, ale korekciu, resp. doplnenie prezentácií na základe nových poznatkov, sme predpokladali.

\section{Variant I.}

Celková charakteristika: Dominancia primárnej etapy, zohl’adnenie vybratých mladších prvkov, povrchová úprava - náznaková rekonštrukcia primárnej omietky.

Základná metodika: Synteticko-rekonštrukčná metóda s použitím „kontraanalytiky“ a dôrazom na výtvarné a optické scelenie.

Ťažisko: Primárna fáza.

\section{A. Celkové pokyny}

Vychádza z princípu v čo najväčšej miere evokovat' primárny charakter interiéru. Predpokladá celkové preomietnutie všetkých plôch interiéru omietkou až po úroveň podlahy, imitujúcou primárnu povrchovú úpravu (A). Štíty omietnut' po odskoky, ktoré reprezentujú úroveň zachovania primárneho muriva a $v$ bočných častiach naznačit' omietkový priebeh podl'a fragmentu na juhozápadnom ukončení. Na západnom štíte prezentovat’ mapy omietky B s výzdobou. Na

11 Táto korekcia bola medzičasom zrealizovaná. 


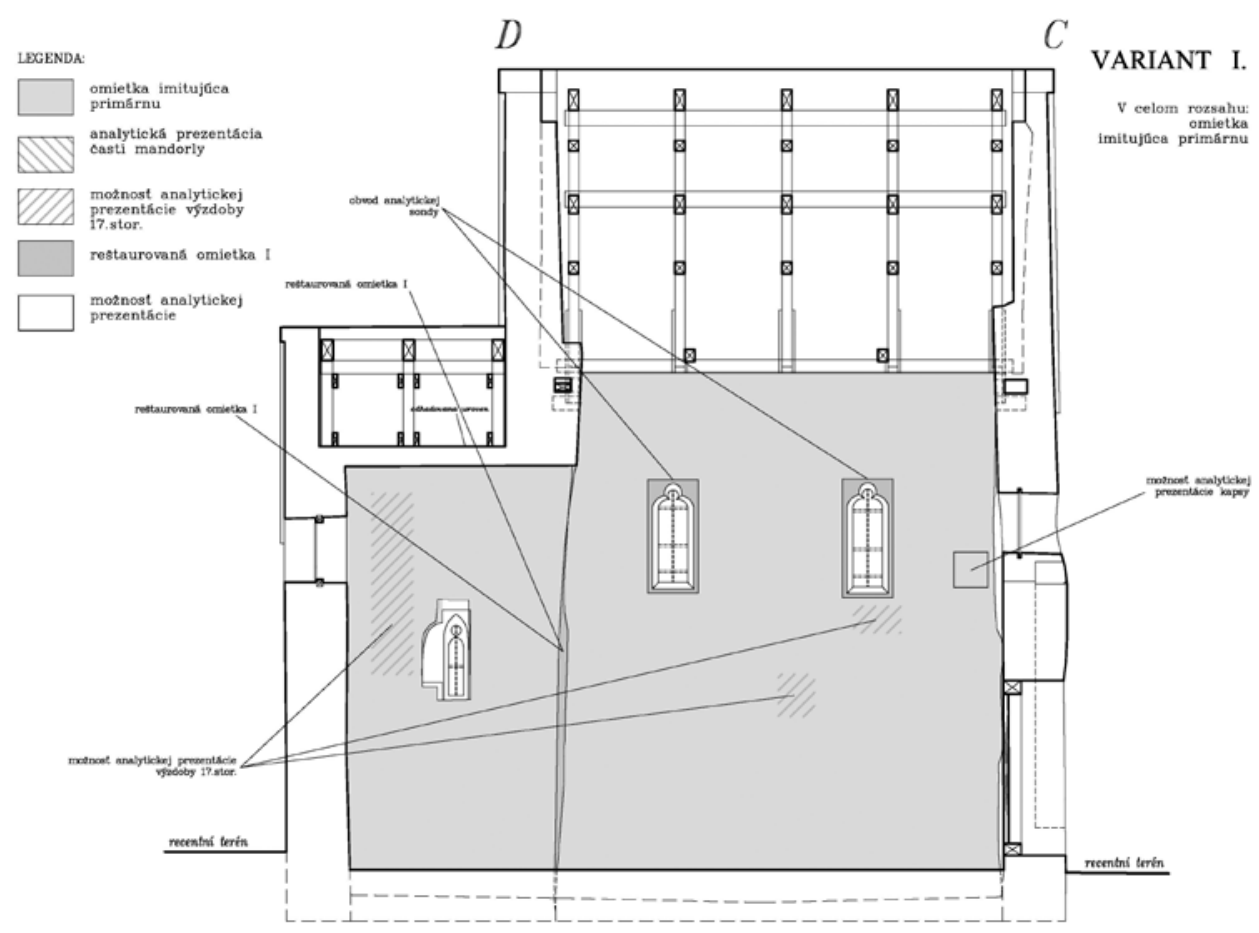

Obr. 16. Kopčany, okr. Senica, Kostol sv. Margity Antiochijskej. Variant I. - južná stena.

Abb. 16. Kopčany, Bezirk Senica, Kirche St. Margaretha von Antiochien. Variante I. - Südwand.

bočných stenách vytiahnut' novú omietku až po korunu novej rímsy, nakol'ko primárne murivo dosahovalo až po ňu. V rámci dôrazu na primárnu stavebnú etapu doporučujeme na vybratom mieste/-ach prezentovat' priamo prvotnú omietkovú úpravu (A), prípadne vrstvu po nej následnú (B). Na podlahu uplatnit' rekonštrukciu maltovo-hlinitej úpravy. V rámci bližších pokynov jednotlivých stien doporučujeme prezentácie vybraných častí výzdob analyticky. Nakol'ko je však povrchová úprava navrhnutá ako rekonštrukcia primárnej, ich priamym prezentovaním pôjde vzhl'adom na úroveň povrchov de facto o akési kontraanalitiky. Mladšie vrstvy budú ustupovat' voči staršej rekonštruovanej. Otáznym ostáva miesto osadenia menzy, ked’že pôvodný základ nebol zistený. Aj ked' mobiliárové riešenie nebolo predmetom návrhov, rámcovo navrhujeme jej osadenie najpravdepodobnejšie k primárnej situácii - na rozhranie svätyne a lode. Mala by mat' formu murovanej podnože a kamennej platne, s dôrazom na rudimentárny výtvarný výraz.

\section{B. Prezentácie jednotlivých stien}

Na západnej stene lode možnost' vyznačit' ryhou v omietke oblúk ostenia portálu (obvod) a rovnako obrys mladšieho zamurovaného okna. Možnost' prezentovat' čast' omietky B a analyticky prezentovat' časti pásových výzdob. Na severnej stene lode prezentovat' fragmenty stredovekej mandorly ako analytickú sondu. Možnost' prezentovat' vybranú čast' výmal'by 17 . storočia (strapcový pás, čast' drapérie) analytickou sondou a kapsy empory ustúpenou omietkou bez povrchovej úpravy (detto na južnej stene lode). Osekané hrany ostení na styku východnej steny lode a priestoru svätyne ponechat' a na nich reštaurovat' omietkovú vrstvu I., ked’že k osekaniu došlo v mladšej etape.

Na južnej stene svätyne ponechat' súčasnú prezentáciu časti primárneho otvoru a mladšieho mníškového okna. Možnost' prezentovat' časti oboch vrstiev výmal'by 17. storočia analytic- 
LEGENDA:

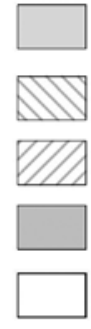

mietka imitujøica primărnu

analytická prezentácia cast1 mandorly

moznost analytickej prezentácie vyzdoby 7.stor.

restaurovaná omietka

moznost analytickej prezentăcie

\section{(n)}

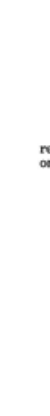

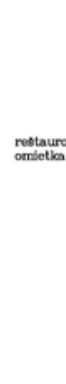

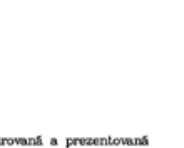

motnost anelytickes

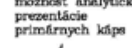

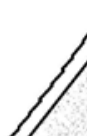

VARIANT I.

$\mathrm{V}$ celom rozsahu:
omietka imitujuca primárnu

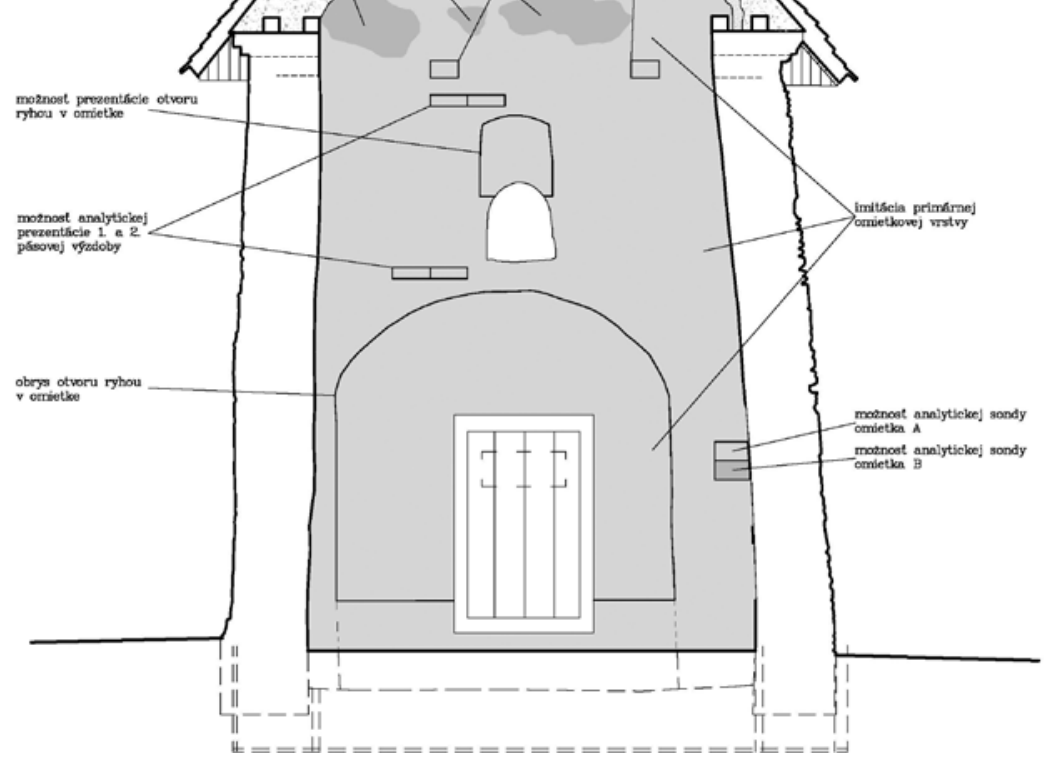

Obr. 17. Kopčany, okr. Senica, Kostol sv. Margity Antiochijskej. Variant I. - západná stena.

Abb. 17. Kopčany, Bezirk Senica, Kirche St. Margaretha von Antiochien. Variante I. - Westwand.

kou sondou, zasahujúcou spoločne stenu i klenbu (detto na severnej stene svätyne). Otvor (niku) v severnej stene neprezentovat', ak sa prijatel’ne nevysvetlí jeho funkcia. Spôsob prezentácie na klenbe sa upresní podl’a nálezov doplnkového reštaurátorského výskumu. Pri vytvorení novej omietky, imitujúcej primárnu, je možnost' prezentovat' vybrané časti oboch vrstiev výmal'by 17. storočia analyticky. Na východnej stene svätyne analyticky prezentovat' fragment nástennej mal'by s tvárou, ktorý s najväčšou pravdepodobnost'ou predstavuje sv. Margitu. Možnost' prezentovat' analyticky aj pilaster (čast') zo 17. storočia, ako aj datovanie AD 1647, prípadne iné ryté nápisy.

\section{Variant II.}

Celková charakteristika: Dominancia stredovekých úprav, zohl'adnenie vybratých mladších prvkov, povrchová úprava - reštaurovanie a rekonštrukcia stredovekej omietky.

Základná metodika: Synteticko-rekonštrukčná metóda s použitím analytiky starších prvkov a „kontraanalytiky“ mladších a s dôrazom na výtvarné a optické scelenie.

Ťǎisko: Stredoveké fázy. 
LEGENDA:

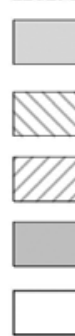

omietka imitujuca primárnu

analyticka prezentácia casti mandorly

mo2nost analytickej prezentácie vyzdoby 17.stor.

restaurovaná omietka I

mo2nost. analytickej prezentăcie

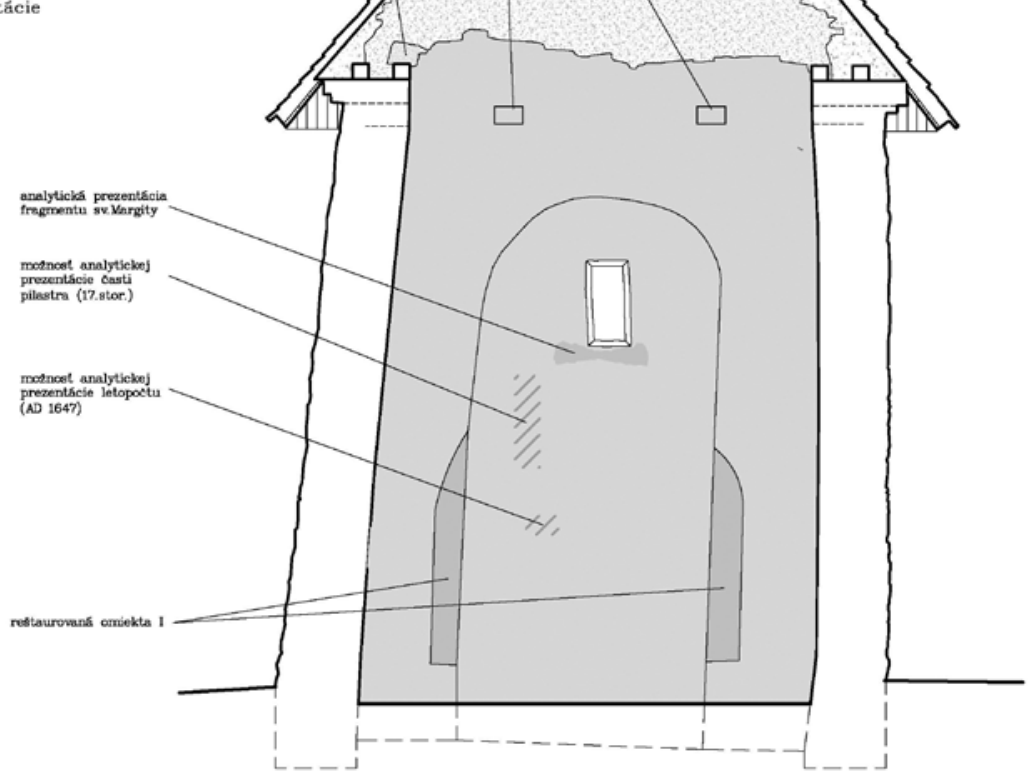

Obr. 18. Kopčany, okr. Senica, Kostol sv. Margity Antiochijskej. Variant I. - východná stena.

Abb. 18. Kopčany, Bezirk Senica, Kirche St. Margaretha von Antiochien. Variante I. - Ostwand.

\section{A. Celkové pokyny}

Vychádza z princípu dominantného vyznenia stredovekých úprav s rešpektovaním miest odkryvu primárnej vrstvy. Reštaurovat' navrhujeme stredovekú omietkovú vrstvu (E, F, príp. I, J) v miestach, kde je vel'koplošne odokrytá a súvislejšie zachovaná bez prekrytia vrstvou 17. storočia. Na vrstve 17. storočia a na odhalených častiach murív doplnit' novú omietku, imitujúcu charakterom stredoveké. Hrúbka bude závislá od podkladovej plochy (omietka, murivo), niekde i použitie pačokovo-náterovej vrstvy. Ponechat' niektoré odkryvy vrstvy B ako analytické sondy. Na zámurovke stredovekého portálu sa interiér preomietne omietkou evokujúcou primárnu podobu (A, B), mierne ustúpenou oproti okolitej vrstve, ked’že táto obnovuje stredoveký stav. Omietka sa zrealizuje na štítoch len po úroveň predpokladaného rovného stropu (omietka s ryskou). Nad ním sa v rozsahu zachovanej primárnej časti omietnu štíty omietkou imitujúcou vrstvu A s prezentáciou zachovaných častí vrstvy B, ako vo Variante I. Na bočných stenách sa až po úroveň koruny doplní vrstva imitujúca stredovekú omietku.

Odkopané časti muriva sa prekryjú omietkovou vrstvou imitujúcou stredovekú (E, F) úpravu, a to do výšky stredovekej podlahy, ca $25 \mathrm{~cm}$ rozdiel od terajšej. Zvyšok muriva pri zemi dostane omietku imitujúcu primárnu úpravu A, pre prípad, že sa podlahová úroveň ponechá v súčasnej nivelete, zníženej na pôvodnú. Alternatívne navrhujeme rekonštruovat’ tehlovú stre- 


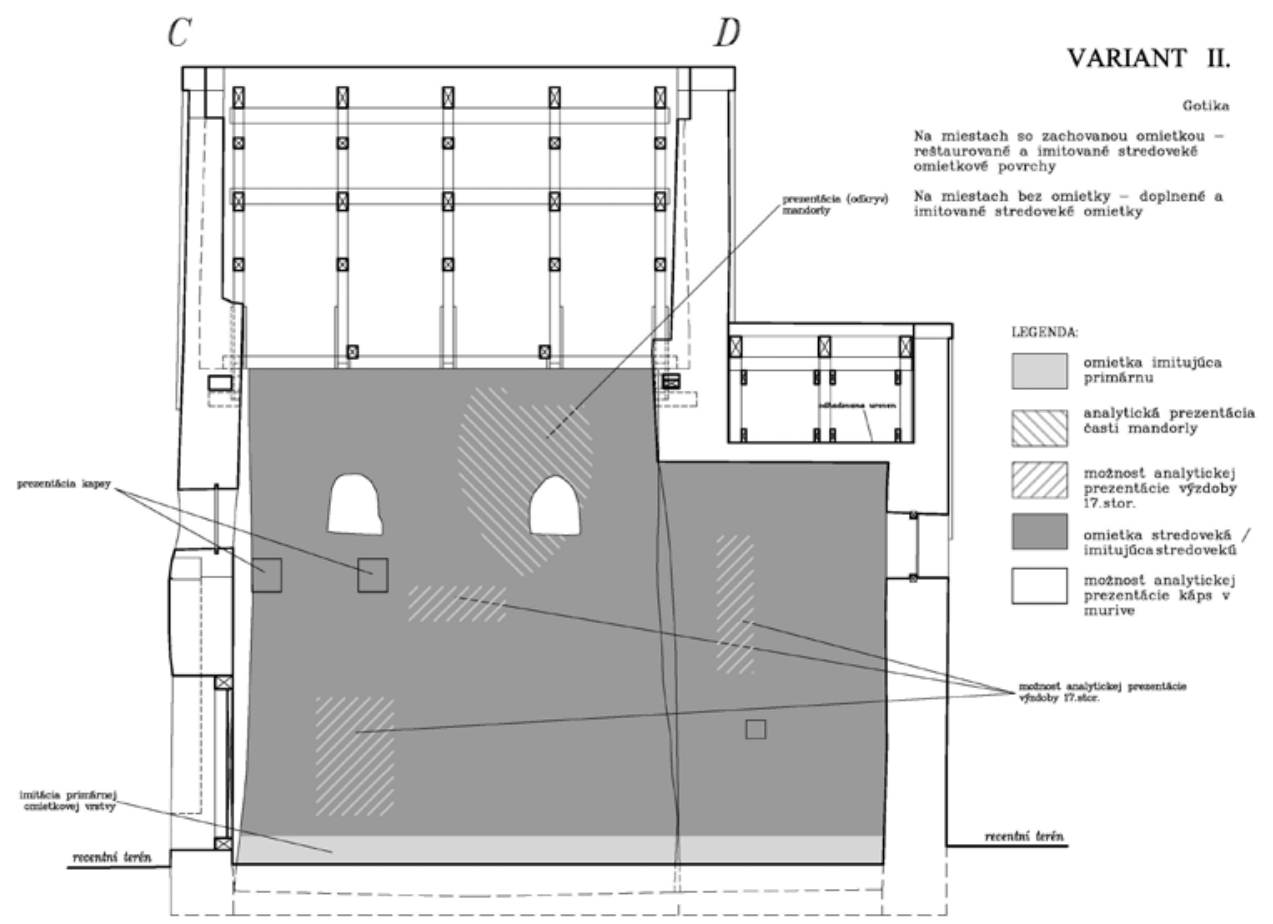

Obr. 19. Kopčany, okr. Senica, Kostol sv. Margity Antiochijskej. Variant II. - severná stena.

Abb. 19. Kopčany, Bezirk Senica, Kirche St. Margaretha von Antiochien. Variante II. - Nordwand.

dovekú dlažbu podl’a zistení výskumu v jej nivelete. Na pôvodné miesto pred svätyňu navrhujeme zrekonštruovat' oltárny stipes s použitím pôvodnej menzy. Nepredpokladáme odstránenie zámurovky stredovekého portálu, ale ponechanie evokovania primárneho stavu.

\section{B. Prezentácie jednotlivých stien}

Zámurovku západnej steny upravit’ omietkou imitujúcou primárnu, ktorá bude realizovaná s ustúpením ca $2 \mathrm{~cm}$ oproti lícu stredovekého povrchu, čím sa vyznačí i oblúk ostenia portálu. Možnost' prezentovat' čast' omietky B. Na stene doporučujeme rekonštruovat' 1 . fázu pásovej výzdoby, 2. fázu ponechat' a prekryt'. V celom rozsahu odokryt' a prezentovat' stredovekú mandorlu na severnej stene lode, chýbajúce časti doplnit' do tvaru $\mathrm{v}$ jemnom farebnom tóne. Možnost' prezentovat' čast' výmal'by 17. storočia analytickou sondou a kapsy empory ustúpenou omietkou bez povrchovej úpravy. Rovnako pristupovat' pri obnove južnej steny lode. Osekané hrany na styku svätyne a východnej steny lode ponechat'. Na nich reštaurovat' omietkovú vrstvu I. Ponechat' súčasnú prezentáciu časti primárneho otvoru a mladšieho mníškového okna na južnej stene svätyne. Možnost' prezentovat' čast' výmal'by 17. storočia analytickou sondou zasahujúcou spoločne stenu i klenbu (obe následné vrstvy) na severnej i južnej stene svätyne. Spôsob prezentácie klenby sa upresní podl'a nálezov doplnkového výskumu. Na ranobarokovej stabilizovanej vrstve 17. storočia sa vytvorí nová tenká omietková vrstva. Imitovat' bude primárnu vrstvu A alebo stredovekú, ak ju nálezy potvrdia. Aj na klenbe je možnost' prezentovat' čast' výmal'by 17. storočia analytickou sondou. Na východnej stene doporučujeme analyticky prezentovat' fragment nástennej mal'by s tvárou (sv. Margita?), prípadne prezentovat' analyticky pilaster zo 17. storočia, ako aj datovanie AD 1647, nakol'ko uvedeným fragmentom prisudzujeme dôležitú výpovednú schopnost' o hodnotách a vývoji úprav objektu. 


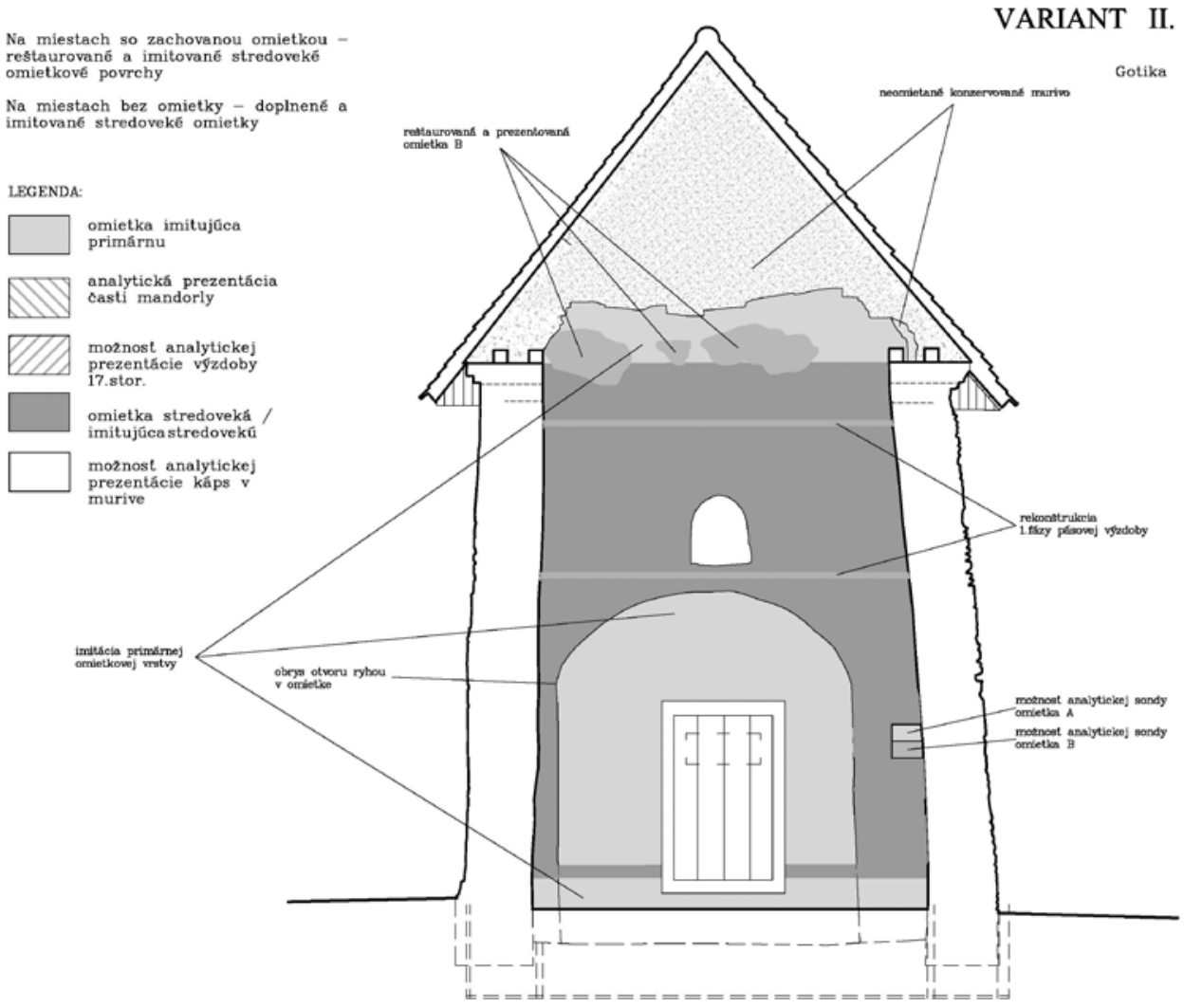

Obr. 20. Kopčany, okr. Senica, Kostol sv. Margity Antiochijskej. Variant II. - západná stena.

Abb. 20. Kopčany, Bezirk Senica, Kirche St. Margaretha von Antiochien. Variante II. - Westwand.

\section{Variant III.}

Celková charakteristika: Optická prezentácia viacerých hodnotných vrstiev podla miery zachovania v kontinuálnom prehl'ade. Zohl'adnenie vybratých starších i mladších prvkov, povrchová úprava - reštaurovanie zachovaných hodnotných omietok a náznaková rekonštrukcia podl’a situácie.

Základná metodika: Reštaurátorsko-synteticko-analytická metóda s dôrazom na výtvarné a optické scelenie.

Ťažisko: Kontinuálny výraz vývoja.

\section{A. Celkové pokyny}

Vychádza z požiadavky preukázania kontinuálneho stavu vývoja interiérových úprav v rámci primárnych hmotovo-priestorových kvalít a rešpektovania dimenzií interiéru podl’a primárnej etapy, s uplatnením stredovekých zásahov, s dôraznejším uplatnením vrstvy etapy 17. storočia. Navrhujeme v celom rozsahu reštaurovat' vrstvu zo 17. storočia, ktorá je v objekte zachovaná najcelistvejšie. Vrstvu nedopĺn̆at', skôr odkryt' ňou prekryté hodnotné miesta starších výzdob (mandorla). Staršie vrstvy prezentovat' v miestach jej úbytkov v závislosti od konkrétnej situácie. Prechody vrstiev zjemnit'. Reštaurovat' výzdobu, chýbajúce plochy dopín̆at' spôsobom 


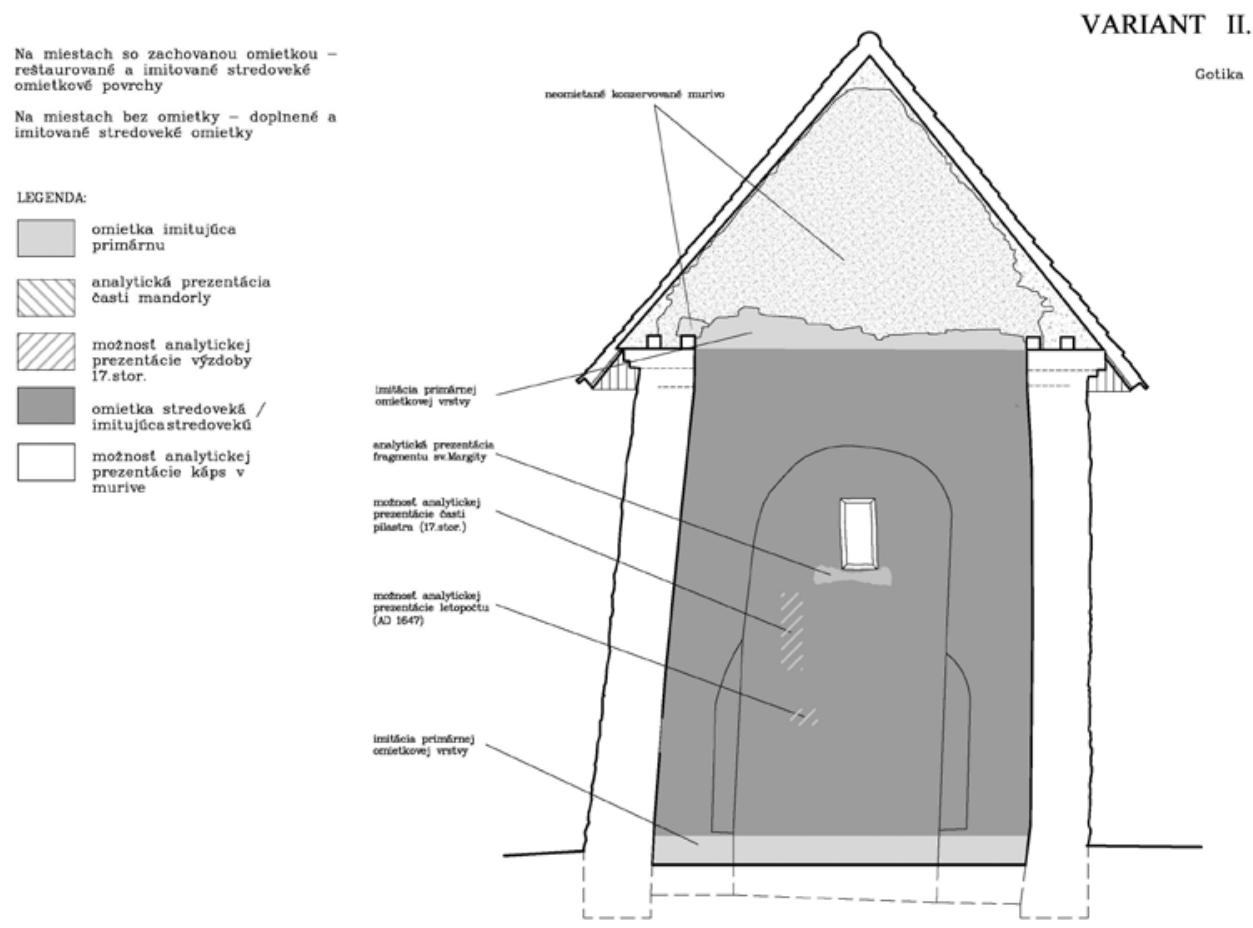

Obr. 21. Kopčany, okr. Senica, Kostol sv. Margity Antiochijskej. Variant II. - východná stena.

Abb. 21. Kopčany, Bezirk Senica, Kirche St. Margaretha von Antiochien. Variante II. - Ostwand.

jemného naznačenia farebného tónu spôsobom „sfumata“. V prípade väčších úbytkov (južná stena lode) prezentovat' len zachované fragmenty a vrstvu upravit’ jemným základným/smotanovým tónom. Na miestach odhalených murív dopíňat' omietky imitujúce vrstvu podl'a konkrétnej situácie (17. storočie alebo stredoveké). Nakol'ko čast' omietky na východnej, južnej a severnej stene svätyne bola pôvodne prekrytá oltárom, táto plocha ostane upravená jednoduchým vápenným náterom. Na bočných stenách realizovat' omietku po úroveň odstráneného stropu. Na nadmurovke imitovat' primárnu omietkovú vrstvu. Alternatívne možno uplatnit' charakter omietky 19. storočia a zrealizovat' ho aj na nových neomietaných murivách koruny. Miernym ustúpením a obrysom možno prezentovat' kapsy trámového stropu. Primárne okenné otvory budú prezentované ako analytiky s užším výrezovým obrysom, alebo omietka bude dotiahnutá $\mathrm{k}$ ich špaletám. Na štítoch je možné omietku zrealizovat' po úroveň fragmentu omietky s rytou líniou, ktorá označuje dobovú úroveň stropu. Nad ňou realizovat' imitáciu omietky A s prezentáciou častí omietky B. Nadmurované časti štítov ponechat' neomietané. V prípade ponechania súčasnej zníženej nivelety podlahy sa odkopané časti muriva prekryjú omietkovou vrstvou, imitujúcou primárnu úpravu $\mathrm{A}$. V interiéri nepredpokladáme obnovu pomerov 17. storočia (niveleta, zámurovka portálu), nakol'ko úroveň exteriéru bola znižovaná na primárny stav a podl’a príslušných stanovísk nebude zmenená. V tom prípade je otázka osadenia menzy. Ked’že pre výškové pomery by nebola možná rekonštrukcia stavu 17. storočia, navrhujeme formu rekonštrukcie stredovekej podoby ako vo Variante II. Alternatívne možno podlahu zodvihnút' na niveletu 17. storočia. Ak by ostal vstup v podobe súčasnej rekonštrukcie výškových pomerov, musela by sa podlaha tesne pri ňom znižovat' a úrovne podláh prekonat' stupňami, čo by však daný malý priestor stiesňovalo. Potom by bolo logickejšie zdvihnutie úrovne exteriéru a obnovenie vel'kého stredovekého portálu. Menza by sa potom realizovala ako rekonštrukcia posledného stavu. Túto alternatívu sme ale graficky neprezentovali. 


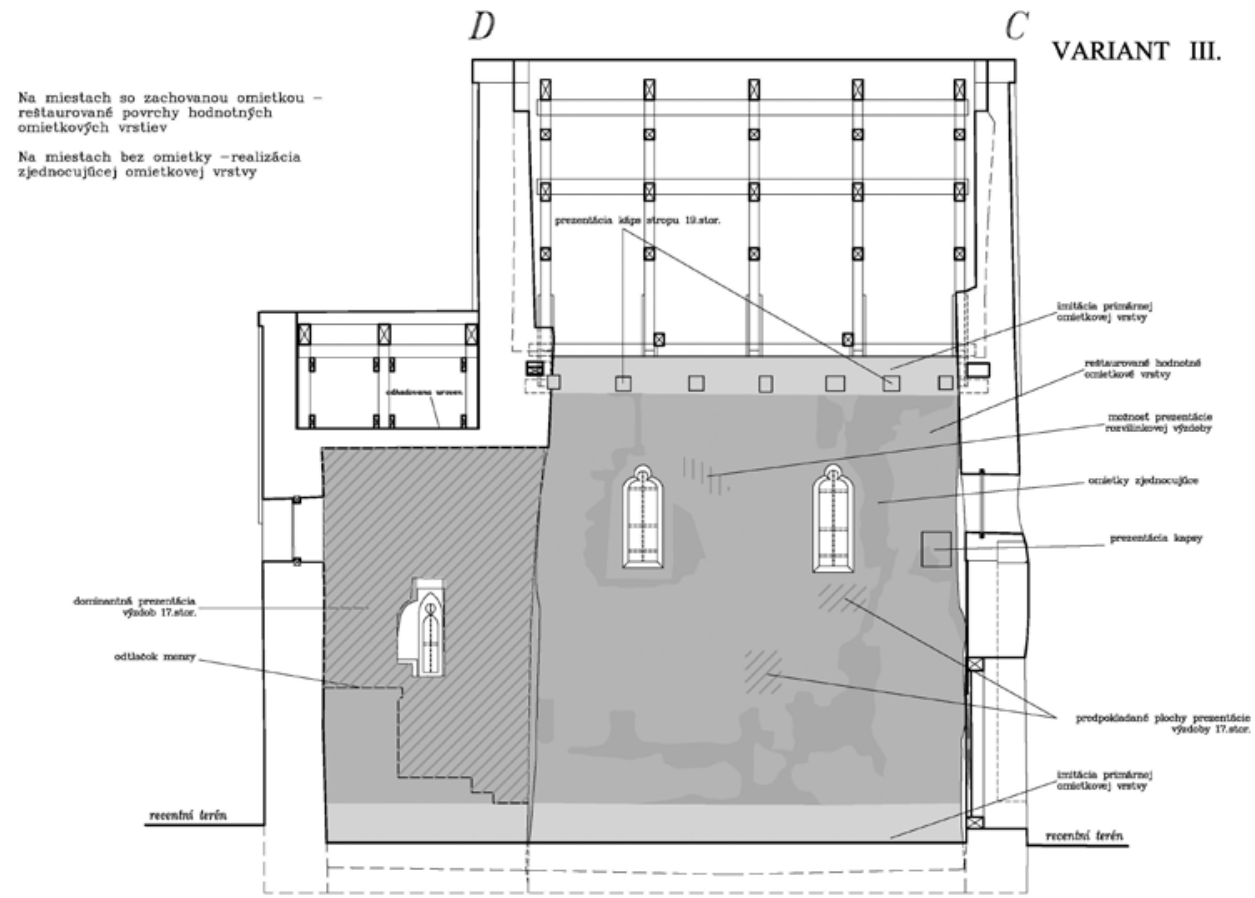

Obr. 22. Kopčany, okr. Senica, Kostol sv. Margity Antiochijskej. Variant III. - južná stena.

Abb. 22. Kopčany, Bezirk Senica, Kirche St. Margaretha von Antiochien. Variante III. - Südwand.

\section{B. Prezentácie jednotlivých stien}

Novodobá zámurovka portálu na západnej stene bude mat'omietku imitujúcu primárnu úpravu A (B) a jej plocha bude ca $2 \mathrm{~cm}$ ustúpená oproti okolitej vrstve. Podobne možno prezentovat' zvyšok mladšieho okna - na jeho zámurovke imitovat' omietku A (B). Možnost' prezentovat' analyticky čast' omietky B. Na stene navrhujeme rekonštruovat' 2. fázu pásovej výzdoby a možnost' analyticky prezentovat' čast' 1 . fázy. Odkryt' celú zachovanú čast' mandorly na severnej stene - reštaurovat' ju a prezentovat', chýbajúce časti doplnit' do tvaru v jemnom farebnom tóne. Prezentovat' kapsy empory ustúpenou omietkou bez povrchovej úpravy (aj na južnej stene). Možnost' odkryvu a prezentácie prípadných zvyškov rozvilinkovej výmal'by okolo zaniknutého termálneho okna južnej steny lode. V častiach vel'kých úbytkov vrstvy 17. storočia reštaurovat' a prezentovat' stredoveké omietky (E, F, G). Osekané hrany ostení svätyne a lode ponechat', na nich reštaurovat' omietkovú vrstvu I. a prezentovat' fragmenty členenia (sokel, pätky). Ponechat' súčasnú prezentáciu časti primárneho otvoru a mladšieho mníškového okna na južnej stene lode. Na južnej i severnej stene navrhujeme reštaurovat' 2. barokovú výzdobu s možnostou analyticky prezentovat' 1 . barokovú výzdobu. Na východnej stene navrhujeme ako analytickú prezentáciu ponechat' fragment nástennej mal'by tváre (sv. Margita) a výmal'bovú vrstvu iluzívnej architektúry odokryt' v celom rozsahu. Nezachované časti doplnit' do tvaru v tónovom odstúpení. $\mathrm{Na}$ severnej, južnej a východnej stene ponechat' $v$ mieste menzy jej odtlačok a plochu s náterom. V rámci tejto plochy navrhujeme na východnej a severnej stene prezentovat' letopočet AD 1647 a ryté nápisy, ked’že sú na uvedenej vrstve, hoci boli pôvodne prekryté oltárom. Na klenbe reštaurovat' 2 . barokovú výzdobu, možnost' analyticky prezentovat' 1. barokovú výzdobu. V prípade nálezu starších vrstiev sa spôsob prezentácie upraví. Nakol'ko sme vychádzali zo skutoč- 


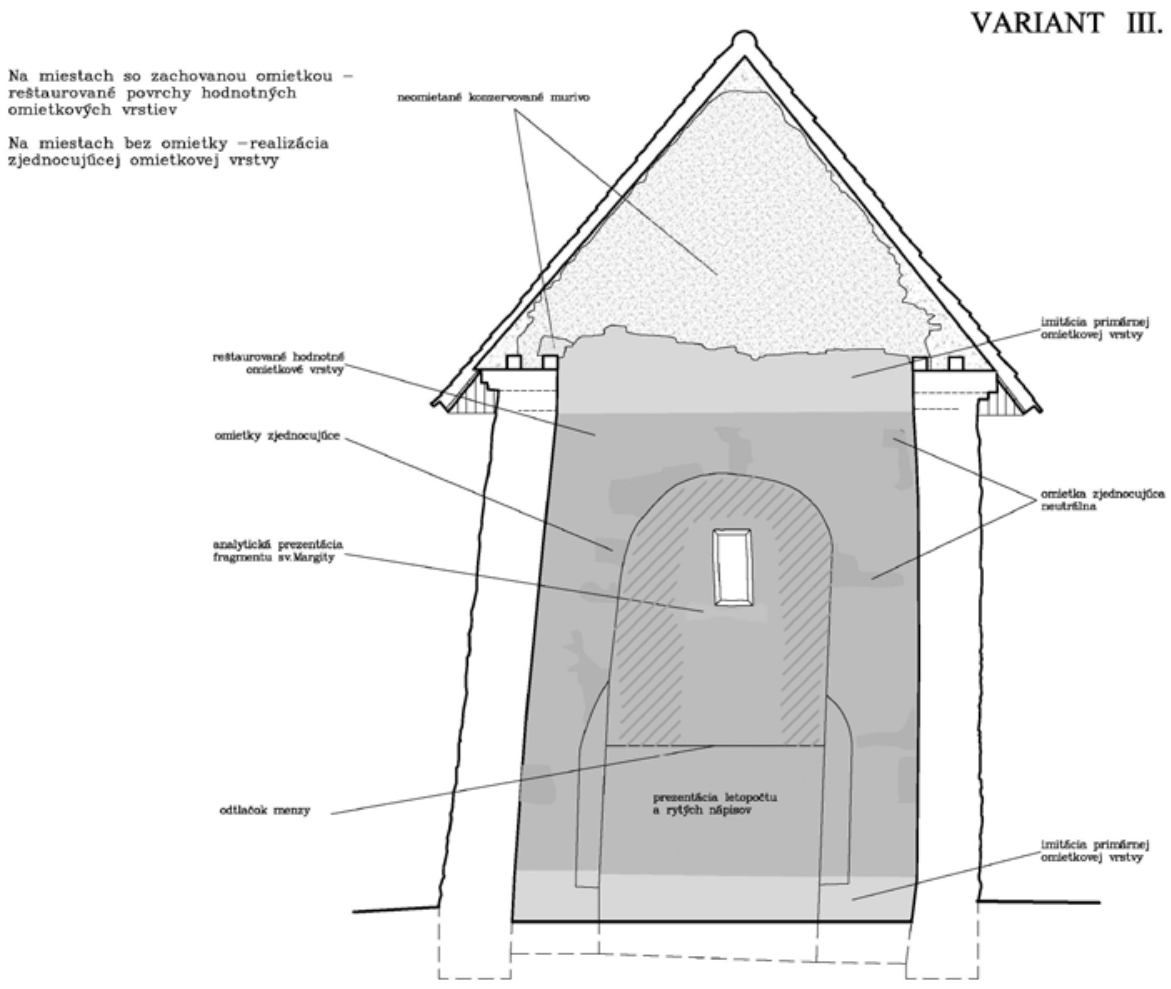

Obr. 23. Kopčany, okr. Senica, Kostol sv. Margity Antiochijskej. Variant III. - východná stena.

Abb. 23. Kopčany, Bezirk Senica, Kirche St. Margaretha von Antiochien. Variante III. - Ostwand.

nosti preferencie ponechania zníženej nivelety, pás muriva medzi úrovňou podlahy 17. storočia a zníženou niveletou bude nutné pojednat imitáciou primárnej vrstvy.

\section{Poznámka k interiérovým prvkom}

Predložené variantné návrhy predkladajú viaceré metodicky opodstatnené možnosti, pričom sa nevenujú d’alšej dôležitej otázke, akou je riešenie interiérových liturgických prvkov hlavne umiestnenia a formy oltárnej menzy, ale i prípadných iných prvkov, ako sú svietniky, ambo a pod. ${ }^{12}$ Sprievodnou otázkou je aj budúce využitie objektu - momentálne sa zdá, že pôjde o spojenie „memoriálnej“ funkcie s občasnou liturgicko-bohoslužobnou. ${ }^{13}$ Pri takomto type pamiatky vo významovej rovine nepôjde len o obnovu pamiatky a jej prírodného prostredia, ale o znovupotvrdenie sakrálneho zmyslu miesta (Polomová 2001, 34).

\section{Oltár}

Doporučujeme v zásade tieto spôsoby:

a) Náznakové rekonštrukcie smerujúce k slohovému výrazu

- Náznakovú formu v podobe murovaného stipesu s použitím doterajšej kamennej menzy vol'ne vo svätyni.

12 V rámci výučby na FA STU sme ja i iní kolegovia (Gregorová, Pauliny) zadali študentom túto problematiku v rôznych úrovniach - napr. na ateliérovej tvorbe 3. a 4. ročníku, i v rámci diplomového projektu.

13 Objekt je v cirkevnom vlastníctve. 
- Náznakovú formu stredovekej podoby v podobe murovaného stipesu s použitím doterajšej kamennej menzy a kamenného bloku (špecifický prípad rekonštrukcie stredovekej situácie).

\section{b) Rekonštrukcia slohová}

- Rekonštrukcia murovaného stipesu s použitím doterajšej kamennej menzy na zadnej stene svätyne - krajná poloha rekonštrukcie stavu od 17. storočia.

c) Výtvarné diela - náznakové rekonštrukcie ako symbolu

- Ide o výsostne výtvarné, svojbytné návrhy, ktoré zohl’adňujú funkciu oltára a vyjadrujú jeho význam v symbolicko-výtvarnej réžii. Vol’né asociácie kompozičných výtvarných postupov s vysokou mierou invencie.

\section{Fragmenty článkov}

V rámci interiéru je možné vo forme artefaktov výtvarne prezentovat' d’alšie hodnotné detaily pochádzajúce z kostola: kamennú platňu, sekundárne použitú ako oltárny stupeň v 17. storočí, fragment kamenného článku zo zásypu, kamenný blok, sekundárne použitý v základoch stredovekej menzy.

V týchto návrhoch sme považovali za samozrejmé, že konkrétne prezentácie môžu zmenit' prípadné nové nálezové situácie starších výzdob výnimočného charakteru, hlavne na klenbe a na západnej stene. Zvolená metodika obnovy interiéru musí vychádzat' zo zohl'adnení všetkých súvislostí, hodnôt a nielen dôležitosti primárnej etapy, ale dokladu celého stáročného vývoja tejto najstaršej pamiatky na našom území. Ako vidno, uplatnenie exaktného prístupu, zvažovanie všetkých hodnôt objektu, ich hierarchie a výpovednej schopnosti, spolu so zohl'adnením technických a technologických otázok, ako aj jasne definovaný predmet ochrany vedú k stanoveniu viacerých možností rámcovej metodiky obnovy, ktorá dáva priestor pre d’alšie kreovanie konkrétnych situácií variantnými modelmi. Je zrejmé, že vol'ba tej-ktorej možnosti závisí od hierarchizácie hodnôt, a nielen od ich rozvrstvenia či prípadného vizuálneho komplexu. Sme presvedčení, že zložitost' zmienenej problematiky obnovy a prezentácie interiéru bude príslušný KPÚ riešit' aj komisionálne za prítomnosti expertov, kde zaiste nebudú absentovat' autori spracovaného elaborátu.

Fotografie A. Botek

Grafická čast' A. Botek, R. Erdélyi, B. Vachová

\section{Literatúra}

BAGIN, Anton, 1992: Kopčany pri Holíči iba 600-ročné?, Katolícke noviny, č. 33, 13.

BAXA, Peter a kol., 2004: Baxa, Peter-Ferus, Viktor-Glaser-Opitzová, Renáta-Katkinová, Jana, Vel'komoravský kostol v Kopčanoch, Pamiatky a múzeá, č. 4, 65.

BAXA, Peter a kol., 2005: Baxa, Peter-Ferus, Viktor-Glaser-Opitzová, Renáta-Katkinová, Jana, Vel'komoravské hroby pri Kostole sv. Margity Antiochijskej v Kopčanoch, Pamiatky a múzeá, č. 3, 48-50.

BOTEK, Andrej, 2007: Kostol sv. Margity Antiochijskej v Kopčanoch, Pamiatky a múzeá, č. 4, 41-45.

- 2007a: Kostol sv. Margity Antiochijskej v Kopčanoch - výsledky výskumov a metodické otázky obnovy. In: Studia archeologica Slovaca Mediaevalia VI. Zborník príspevkov zo sympózia Kostol ako stred sídliskovej jednotky. Kláštorisko, 31. august - 2. september 2006, 97-102. Bratislava.

-2010: Kostol sv. Margity v Kopčanoch - vývojové etapy a otázky metodiky obnov, Monumentorum Tutela - Ochrana pamiatok 22, 29-51. Bratislava.

BOTEK, Andrej-ERDÉLYI, Róbert-VACHOVÁ, Barbora, 2011: Kostol sv. Margity Antiochijskej, Kopčany. Architektonicko-historický výskum interiéru štítov a návrh obnovy interiéru. Uložené na KPÚ Trnava (súčast' spisu, bez sign.).

- 2013: Nálezy zvyškov zaklenutia lode kostola v Kopčanoch, Pamiatky a múzeá, č. 2, 38-41. 
BOTEK, Andrej-GREGOROVÁ, Jana-PALGUTOVÁ, Katarína, 2011: Prípravná dokumentácia ku kompletizácii podkladov Kostola sv. Margity Antiochijskej v Kopčanoch - 2. čast'. Fakulta architektúry, STU Bratislava. Uložené na KPÚ Trnava (súčast' spisu, bez sign.).

BOTEK, Andrej-ÚRADNÍČEK, Vladimír, 1998: Kostolík sv. Margity Antiochijskej Kopčany. Záverečná správa. Výskumná úloha 7/95, Výskum sakrálnej architektúry. Vysoká škola výtvarných umení, Katedra reštaurovania. Uložené na KPÚ Trnava (súčast' spisu, bez sign.).

GREGOR, Pavel, 2008: Kultúrne pamiatky a ich hodnoty, interpretácia a prezentácia kultúrno-historických hodnôt pri ochrane a obnove architektonického dedičstva. Determinanty vol'by metódy ochrany a obnovy pamiatok. In: Gregor, P. a kol., Obnova pamiatok, 67-70. Bratislava.

KVASNICOVÁ, Magdaléna, 2007: Patrocínium sv. Gála v stredovekej architektúre na Slovensku. In: Studia archeologica Slovaca Mediaevalia VI. Zborník príspevkov zo sympózia Kostol ako stred sídliskovej jednotky. Kláštorisko, 31. august - 2. september 2006, 53-82. Bratislava.

PAULINY, Pavol, 2007: Archeologický park Mikulčice - Kopčany. Projekt. Slovenská architektonická revue, č. 5-6, 16-21.

POLOMOVÁ, Beata, 2001: Duch v krajine - vnímanie / uznanie / tvorenie. In: Krajina - človek - kultúra, VI. celoslovenská konferencia. Zborník referátov, 33-37. Banská Bystrica.

PUŠKÁR, Juraj, 2001: Návrh na reštaurovanie gotických okien Kostola sv. Margity Antiochijskej v Kopčanoch. Archív KPÚ Trnava, Zbierka reštaurátorských dokumentácií, sign. R173.

PUŠKÁR, Juraj-MÝTNIK, Vojtech, 2004: Kostol sv. Margity Antiochijskej v Kopčanoch. Návrh na reštaurovanie exteriérových omietok. Archív KPÚ Trnava, Zbierka reštaurátorských dokumentácií, sign. R176.

- 2006: Kostol sv. Margity v Kopčanoch. Podrobný výskum reštaurovaných exteriérových omietok ako doplnok reštaurátorského prieskumu z Návrhu na reštaurovanie exteriérových omietok, 2004 a nové nálezové situácie z južnej a západnej steny lode. Archív KPÚ Trnava, Zbierka reštaurátorských dokumentácií, sign. R 212.

- 2009: Kostol sv. Margity v Kopčanoch. Návrh na reštaurovanie. Západná a južná fasáda. Archív KPÚ Trnava, Zbierka reštaurátorských dokumentácií, sign. R 222.

SABADOŠOVÁ, Elena-HAVLÍK, Marián, 1999: Kostol sv. Margity Antiochijskej, Kopčany. Správa o výsledkoch architektonického výskumu 1995-1998. Národné pamiatkové a krajinné centrum. Slovenský ústav pamiatok, Krajské stredisko. Bratislava. Archív PÚ SR Bratislava, Zbierka výskumných správ, inv. č. 1512/a.

- 1999a: Kostol sv. Margity Antiochijskej, Kopčany. Ideový návrh pre obnovu pamiatky, pre jej realizáciu. Pamiatkový ústav - regionálne stredisko, Bratislava. Uložené na KPÚ Trnava (súčast' spisu, bez sign.).

- 2008: Umelecko-historický výskum južnej a západnej fasády lode kostola s vyhodnotením reštaurátorských nálezov počas odstraňovania omietok. Kostol sv. Margity Antiochijskej, Kopčany. Archív KPÚ Trnava, Zbierka výskumných správ, sign. T 692.

ŠURIN, Miroslav-BOTEK, Andrej, 2008: Kopčany, Kostol sv. Margity Antiochijskej. Návrh na reštaurovanie interiéru. Rkp., archív autora.

\section{Zusammenfassung}

\section{Varianten zur Präsentationsmethodik der wertvollen Schichten und Funde im Innenraum der Kirche St. Margaretha von Antiochien in Kopčany}

Die Kirche St. Margaretha von Antiochien in Kopčany ist hinsichtlich der erhaltenen Modifizierungen, Putzschichten, Anstriche, Verzierungen und Malereien sowie der architektonischen Elemente ein hervorragendes Beispiel dafür, bei Fragen zur Methodik ihrer Restaurierung und Präsentation mehrere Varianten in Betracht zu ziehen. Der Gesamtbestand der wertvollen, aus verschiedenen Epochen stammenden und die jahrhundertelange Entwicklung des Objektes bezeugenden Schichten zwingt uns dazu, bei deren Restaurierung nicht schablonenhaft vorzugehen, sondern konsequent die einzelnen Möglichkeiten zu durchdenken, damit durch die jeweils gewählte Methodik keine irreversiblen Schäden am Wertbestand verursacht werden. Als Ausgangspunkt für ihre methodischen Überlegungen dient den Verfassern eine zusammenfassende Übersicht der wichtigsten Funde der aus den einzelnen Bauetappen stammenden Schichten und Verzierungen (Primärputze mit Fragmenten der Farbfassungen, mittelalterliche Mandorla, Fragment eines Gesichts, zwei großflächige Barockschichten mit illusionistischer und figuraler Gliederung usw.). Jedweder Eingriff bei der Renovierung und 
Restaurierung muss diese Bandbreite an Modifizierungen des Putzes und an Verzierungen respektieren, und zwar auch in Fällen, in denen sie optisch nicht direkt präsentiert werden.

Ferner wird von den Verfassern der gegenwärtige Zustand des Objektes zusammengefasst, an dem nach Beendigung der wesentlichen Untersuchungen (restauratorischer und bauhistorischer) verschiedene Teilinstandsetzungen durchgeführt worden sind, mit denen in einigen Fällen ältere Elemente rekonstruiert wurden, die jedoch auch die Zerstörung jüngerer Situationen verursachten. Dabei handelt es sich insbesondere um die Tieferlegung des Höhenniveaus des Innen- und Außenraums, um die Restaurierung und Rekonstruktion primärer sowie mittelalterlicher Kleeblattfenster (wobei ein Thermalfenster im Süden und das Fenster über dem Westeingang entfernt wurden), um die Rekonstruktion des Eingangs, um den Abbau der Altarmensa und des Plateaus, auf welchem sie stand u.a. Die aufgeführten Eingriffe wurden jeweils im Hinblick auf die vorherrschende Meinung gewählt, die primäre Gestaltungsetappe des Objektes durch die Restaurierung wiederherzustellen, wobei die Begleitzusammenhänge bei ihrer Realisierung nicht immer konsequent umgesetzt wurden. Der Verfasser erinnert auch an einige wichtige methodische Materialien, die für die Restaurierung des Innenraums - häufig auch in verschiedenen Lösungsvarianten - ausgearbeitet worden sind.

Schwerpunkt des vorliegenden Beitrags ist das von den Verfassern im Rahmen ihrer bauhistorischen Untersuchung zuletzt ausgearbeitete Material des Entwurfs der Restaurierung und Präsentation des Innenraums, wobei die drei Varianten vorgestellt werden, die am geeignetesten erscheinen. Variante I. basiert auf dem Prinzip, in höchstem Maße den primären Charakter des Innenraums herbeizuführen. Sie setzt voraus, dass alle Innenraumflächen mit einem solchen Putz verputzt werden, der die primäre Oberflächenbehandlung bei der anschließenden Fixierung der unter ihm liegenden jüngeren Schichten imitiert. Variante II. basiert auf dem Prinzip einer dominanten Wirkung der mittelalterlichen Umgestaltung unter Respektierung der Stellen, an denen primäre Schichten freigelegt worden sind. Wir schlagen vor, die mittelalterliche Putzschicht an den Stellen zu restaurieren, an denen sie großflächig und ohne von der Schicht des 17. Jahrhunderts überdeckt zu sein, zusammenhängender erhalten geblieben ist. Variante III. geht aus der Forderung hervor, den kontinuierlichen Entwicklungsstand der Innenraummodifizierung im Rahmen der primären Qualitäten bezüglich der Bau - und Raumform nachzuweisen und die Dimensionen des Innenraums entsprechend der primären Etappe zu respektieren, dies unter Verwertung der mittelalterlichen Eingriffe und unter ausdrücklicherer Verwertung der aus der Etappe des 17. Jahrhunderts stammenden Schichten. Bei jeder Variante werden von den Verfassern auf analytische Art und Weise Anweisungen für die jeweilige Behandlung der einzelnen Wände und für die Verwertung wertvoller Funde aus anderen Etappen angegeben, wobei jedoch Berücksichtigung findet, dass der optische Gesamteindruck nicht gestört wird. Abschließend werden auch dahingehend Überlegungen angestellt, wie die Innenraumelemente und das liturgische Mobiliar gestaltet und die lose gefundenen Fragmente von architektonischen Elementen verwendet werden können.

Fotografien A. Botek

Grafischer Teil A. Botek, R. Erdélyi, B. Vachová

doc. Ing. arch. Mgr. Andrej Botek, PhD., Ústav dejín a teórie architektúry a obnovy pamiatok, Fakulta architektúry STU, Nám. slobody 19, SK 81245 Bratislava, Slovenská republika,

andrej.botek@stuba.sk; botek@vsvu.sk

Ing. arch. Róbert Erdélyi, Marcheggská 82, SK 90031 Stupava, Slovenská republika, rb.erdelyi@gmail.com

Ing. arch. Barbora Vachová, Exnárova 28, SK 82103 Bratislava, Slovenská republika, barbora.vachova@gmail.com 
